\title{
Biogenic VOC oxidation and organic aerosol formation in an urban nocturnal boundary layer: aircraft vertical profiles in Houston, TX
}

\author{
S. S. Brown ${ }^{1}$, W. P. Dubé ${ }^{1,2}$, R. Bahreini ${ }^{1,2, *}$, A. M. Middlebrook ${ }^{1}$, C. A. Brock ${ }^{1}$, C. Warneke $^{1,2}$, J. A. de Gouw ${ }^{1,2}$, R. \\ A. Washenfelder ${ }^{1,2}$, E. Atlas ${ }^{3}$, J. Peischl ${ }^{1,2}$, T. B. Ryerson ${ }^{1}$, J. S. Holloway ${ }^{1,2}$, J. P. Schwarz ${ }^{1,2}$, R. Spackman ${ }^{1,2}$, \\ M. Trainer ${ }^{1}$, D. D. Parrish ${ }^{1}$, F. C. Fehshenfeld ${ }^{1,2}$, and A. R. Ravishankara ${ }^{1}$ \\ ${ }^{1}$ NOAA Earth System Research Laboratory, Chemical Sciences Division, 325 Broadway, Boulder, CO 80305, USA \\ ${ }^{2}$ Cooperative Institute for Research in Environmental Sciences, University of Colorado, Boulder, CO 80309, USA \\ ${ }^{3}$ RSMAS/MAC, University of Miami, 4600 Rickenbacker Causeway, Miami, FL 33149, USA \\ *now at: Department of Environmental Sciences, University of California, Riverside, CA, 92521, USA
}

Correspondence to: S. S. Brown (steven.s.brown@noaa.gov)

Received: 19 March 2013 - Published in Atmos. Chem. Phys. Discuss.: 3 May 2013

Revised: 11 October 2013 - Accepted: 23 October 2013 - Published: 22 November 2013

\begin{abstract}
Organic compounds are a large component of aerosol mass, but organic aerosol (OA) sources remain poorly characterized. Recent model studies have suggested nighttime oxidation of biogenic hydrocarbons as a potentially large OA source, but analysis of field measurements to test these predictions is sparse. We present nighttime vertical profiles of nitrogen oxides, ozone, VOCs and aerosol composition measured during low approaches of the NOAA P-3 aircraft to airfields in Houston, TX. This region has large emissions of both biogenic hydrocarbons and nitrogen oxides. The latter category serves as a source of the nitrate radical, $\mathrm{NO}_{3}$, a key nighttime oxidant. Biogenic VOCs (BVOC) and urban pollutants were concentrated within the nocturnal boundary layer (NBL), which varied in depth from 100$400 \mathrm{~m}$. Despite concentrated $\mathrm{NO}_{\mathrm{x}}$ at low altitude, ozone was never titrated to zero, resulting in rapid $\mathrm{NO}_{3}$ radical production rates of $0.2-2.7 \mathrm{ppbv} \mathrm{h}^{-1}$ within the NBL. Monoterpenes and isoprene were frequently present within the NBL and underwent rapid oxidation (up to $1 \mathrm{ppbv} \mathrm{h}^{-1}$ ), mainly by $\mathrm{NO}_{3}$ and to a lesser extent $\mathrm{O}_{3}$. Concurrent enhancement in organic and nitrate aerosol on several profiles was consistent with primary emissions and with secondary production from nighttime BVOC oxidation, with the latter equivalent to or slightly larger than the former. Some profiles may have been influenced by biomass burning sources as well, making quantitative attribution of organic aerosol sources difficult. Ratios of organic aerosol to CO within the NBL ranged from 14 to $38 \mu \mathrm{g} \mathrm{m}^{-3} \mathrm{OA} / \mathrm{ppmv} \mathrm{CO}$. A box model simulation in-
\end{abstract}

corporating monoterpene emissions, oxidant formation rates and monoterpene SOA yields suggested overnight OA production of 0.5 to $9 \mu \mathrm{g} \mathrm{m}^{-3}$.

\section{Introduction}

Organic compounds constitute a large and ubiquitous component of total aerosol mass loading throughout the troposphere (Zhang et al., 2007; Jimenez et al., 2009), with subsequent effects on visibility, climate and human health. The majority of this organic aerosol (OA) is secondary, formed from oxidation of gas-phase volatile organic compounds (VOCs). Although model representations have improved significantly in recent years, there remains considerable uncertainty with respect to the budget and chemical mechanism for production of secondary organic aerosol (SOA) (de Gouw et al., 2005, 2008; Volkamer et al., 2006; Hodzic et al., 2010). Furthermore, while in situ measurements of OA in polluted regions show it to be generally correlated with tracers of anthropogenic emissions and/or combustion, such as acetylene or CO (de Gouw et al., 2005), filter-based measurements of the radiocarbon content of OA suggest that a large fraction of the carbon is modern (Lemire et al., 2002; Lewis et al., 2004; Weber et al., 2007; Schichtel et al., 2008), indicating that biomass burning, biogenic hydrocarbon oxidation or cooking aerosol (Mohr et al., 2012) are large sources. These observations implicate interactions between anthropogenic and 
biogenic emissions as important contributors to SOA in polluted regions (Hoyle et al., 2009; Spracklen et al., 2011).

Oxidation of biogenic hydrocarbons by the nitrate radical, $\mathrm{NO}_{3}$, is one potential OA source that results from such an interaction. The nitrate radical arises from the reaction of $\mathrm{O}_{3}$ with $\mathrm{NO}_{2}$, whose source is nitrogen oxide $\left(\mathrm{NO}_{\mathrm{x}}=\mathrm{NO}+\right.$ $\mathrm{NO}_{2}$ ) emissions from combustion.

$\mathrm{NO}_{2}+\mathrm{O}_{3} \rightarrow \mathrm{NO}_{3}+\mathrm{O}_{2}$

The nitrate radical is highly reactive, being lost to both oxidation reactions and to production of $\mathrm{N}_{2} \mathrm{O}_{5}$, which is readily taken up by heterogeneous reactions on aerosol surfaces (Chang et al., 2011). The nitrate radical normally is a significant oxidant only in the nighttime atmosphere due to its rapid photolysis and reaction with NO (in photochemical steady state with $\mathrm{NO}_{2}$ ) during daytime. It is particularly reactive toward unsaturated functional groups characteristic of many biogenic VOCs (BVOC), including both isoprene and the monoterpenes (Winer et al., 1984). These reactions produce both organic nitrates and organic aerosol in variable yields; in some cases, the SOA yields are considerably larger than those for other common oxidants $\left(\mathrm{OH}, \mathrm{O}_{3}\right)$ (Griffin et al., 1999; Hallquist et al., 1999; Fry et al., 2009, 2011; Ng et al., 2008; Rollins et al., 2009). Unlike isoprene, monoterpene emissions from many tree species are temperature dependent but light independent, such that they may be emitted during both night and day (Fuentes et al., 2000). Several recent model studies that have incorporated literature SOA yield parameterizations for reactions of $\mathrm{NO}_{3}$ with monoterpenes (Griffin et al., 1999) have suggested that $\mathrm{NO}_{3}$-monoterpene reactions may be responsible for a large fraction of regional and global SOA. In the southeastern US, for example, one model study found that $\mathrm{NO}_{3}$ oxidation more than doubles the amount of monoterpene derived SOA and contributes up to $30 \%$ of the total SOA (Pye et al., 2010). In the area near Houston, TX, Russell and Allen (2005) determined that $\mathrm{NO}_{3}$ oxidation of $\beta$-pinene alone is the second largest SOA source in that region after monoterpene ozonolysis reactions. A recent global model attributes $21-27 \%$ of global SOA to $\mathrm{NO}_{3}$ monoterpene reactions for a range of yield parameterizations, with regional influences as large as $60 \%$ of total SOA (Hoyle et al., 2007).

Analysis of a small number of surface level measurements has shown evidence for an $\mathrm{OA}$ source from $\mathrm{NO}_{3}-\mathrm{BVOC}$ oxidation. McLaren et al. (2004) found a diurnal variation in the mixing ratio of monoterpene oxidation products in a forested region of British Columbia, Canada, attributable to nighttime monoterpene oxidation by both $\mathrm{NO}_{3}$ and $\mathrm{O}_{3}$. Iinuma et al. (2007) found evidence for nighttime production of nitroxy-organosulfates, attributed to $\mathrm{NO}_{3}$-monoterpene oxidation, in aerosol samples collected in Bavaria, Germany. Day et al. (2010) found that organonitrate groups account for up to $10 \%$ of OA mass under dry conditions in southern California, but suggested that they are imperfect tracers of particulate phase reactive nitrogen due to their short lifetime with respect to hydrolysis. Rollins et al. (2012) recently reported the diurnal average of particle phase organic nitrate in relation to total OA in Bakersfield, California. They found strong evidence for early evening production dominated by nitrate radical reactions, suggesting this to be the single largest $\mathrm{OA}$ source in the region.

A large fraction of anthropogenic VOCs, such as alkanes and aromatics, tend to be less reactive toward either $\mathrm{O}_{3}$ or $\mathrm{NO}_{3}$ (Atkinson and Arey, 2003; Brown and Stutz, 2012). Although $\mathrm{NO}_{3}$ reactions with anthropogenic alkenes are rapid, SOA yields from $\mathrm{NO}_{3}$ reactions with the most abundant anthropogenic alkenes (i.e., light alkenes) tend to be small or negligible (Gong et al., 2005).

Vertically resolved measurements can provide more detailed information about nighttime chemical transformations, which take place in a stratified boundary layer structure. The nocturnal boundary layer (NBL) is shallow, with heights of tens to hundreds of meters, leading to concentrated buildup of surface level emissions. The residual daytime boundary layer (or residual layer) that overlies the NBL contains pollutants emitted and mixed to higher altitudes during the preceding day. A previous analysis of aircraft data from the northeast US (Brown et al., 2009a) examined nighttime oxidation of the isoprene remaining within the residual layer at sunset. Nighttime isoprene oxidation was a small aerosol source (2-8\% of total OA), but larger than that inferred from photochemical isoprene oxidation due largely to higher SOA yields for $\mathrm{NO}_{3}$ oxidation of isoprene compared to $\mathrm{OH}(\mathrm{Ng}$ et al., 2008). Our previous study did not address nighttime monoterpene oxidation. As with isoprene, oxidation of the daytime monoterpene emission remaining at sunset would occur predominantly within the residual layer, and would not be observable in surface-level measurements. In contrast to isoprene, nighttime monoterpene emission and oxidation also occur at low altitude within the NBL, leading to a spatial difference in the signatures of the two processes. Here, we report nighttime vertical profiles from the NOAA P-3 aircraft in and around Houston, TX, from low approaches to airfields that probed the difference between the residual and nocturnal boundary layers. The Houston region has large emissions of both anthropogenic $\mathrm{NO}_{\mathrm{x}}$ and biogenic VOCs, although biogenic emissions were not likely at their maximum seasonal values during the October night flights. Low altitude enhancements in $\mathrm{NO}_{3}$ radical production, $\mathrm{NO}_{3}$ reactivity, biogenic VOCs and organic aerosol were consistent with nighttime biogenic VOC oxidation and organic aerosol production within the NBL. These observations provide a direct comparison for model predictions of the magnitude of the OA source from nighttime OA oxidation.

\section{Field campaign and experimental methods}

The second Texas Air Quality study took place in AugustOctober 2006, and included ground-, ship- and aircraft-based 
measurements. Three previous publications (Brown et al., 2009b, 2011, 2012) describe nighttime flights of the NOAA WP-3D aircraft during this study. The set of aircraft instrumentation relevant to analysis of nighttime data has also been described in these publications and in an overview paper (Parrish et al., 2008). Briefly, reactive nitrogen and oddoxygen species measured at $1 \mathrm{~s}$ time resolution included $\mathrm{NO}_{3}$ and $\mathrm{N}_{2} \mathrm{O}_{5}$ by cavity ring-down spectroscopy (Dubé et al., 2006; Fuchs et al., 2008), and $\mathrm{NO}, \mathrm{NO}_{2}$, and $\mathrm{O}_{3}$ by chemiluminescence (Ryerson et al., 1998, 1999, 2000). Submicron aerosol composition was measured by an aerosol mass spectrometer (AMS) with $10 \mathrm{~s}$ time resolution (Bahreini et al., 2008). An optical particle counter measured submicron aerosol size distributions, from which surface area and volume were derived, at $1 \mathrm{~s}$ time resolution (Brock et al., 2003). Accumulation mode black carbon mass was measured at 1s time resolution with a single particle soot photometer (Schwarz et al., 2008).

Speciated volatile organic compounds (VOCs) were measured by discrete canister samples (whole air sampler, or WAS), with approximately 80 samples per flight of 8-30 s duration (Schauffler et al., 1999). A smaller set of VOCs was measured sequentially for $1 \mathrm{~s}$ every $17 \mathrm{~s}$ by proton transfer reaction mass spectrometry (PTRMS) (de Gouw and Warneke, 2007). Although the two independent measurements of biogenic VOCs identified the presence of these compounds within the NBL on vertical profiles, the reported mixing ratios did not always agree. The PTRMS generally reported larger values than the WAS (see discussion below). The reason for this discrepancy is not clear. The WAS samples discretely, and may not fully capture rapid variations seen in the continuous measurements from the PTRMS. For the monoterpenes, the WAS reported only $\alpha$-pinene, while the PTRMS represents the sum of all measured compounds. The PTRMS may be subject to interference from other compounds at a given mass. However, previous BVOC comparisons between the two instruments from the TexAQS campaign (Warneke et al., 2010) and previous campaigns (de Gouw et al., 2003; de Gouw and Warneke, 2007) have shown agreement to within $20 \%$ for isoprene and a factor of two for total monoterpenes.

Figure 1 shows a map of the Houston area together with the spatial distribution of monoterpene emissions and $\mathrm{NO}_{\mathrm{x}}$ sources. The heavy yellow line denotes the boundary of the urban area, and white lines indicate the location of major roadways. There is a large concentration of $\mathrm{NO}_{\mathrm{x}}$ sources associated with the petrochemical industry within the Houston Ship Channel, which extends east from central Houston and is $15 \mathrm{~km}$ north of Ellington Field, where the P-3 was based. The blue-red color scale in the background indicates the emission potential of monoterpenes (i.e., parameterized emissions at a reference temperature of $30^{\circ} \mathrm{C}$ ) from the BEIS3 inventory (Environmental Protection Agency Biogenic Emissions Inventory System 3, http://www.epa.gov/ asmdnerl/biogen.html). Nighttime monoterpene emissions

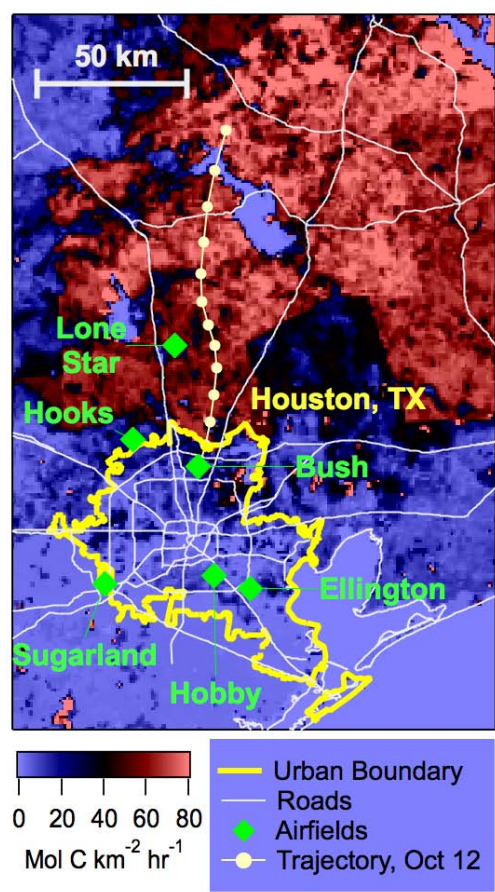

Fig. 1. Map of the Houston, TX, area showing the location of airfields, major roadways (white lines) and monoterpene emission potential (blue-red color scale, legend below) from the BEIS3 inventory. The line with circles is a twelve-hour forward trajectory from Bush airfield on the north side of Houston, beginning at sunset on 12 October (see text).

rates in Houston during the October period investigated here are predicted to have been approximately $50 \%$ of the reference emission rates (calculated at $30^{\circ} \mathrm{C}$ ) based on the temperature dependence in the BEIS3 inventory (Warneke et al., 2010 , see below), but presumably would be larger in midsummer. The green diamonds and labels indicate the locations of airfields used for low approaches on the night flights described here. Low approaches, takeoffs and landings penetrated the NBL to examine emissions and chemistry occurring below $500 \mathrm{~m}$, the nominal cruising altitude for level flight legs during darkness.

\section{Nighttime vertical profiles}

There were four night flights during TexAQS 2006 with a total of 31 nighttime vertical profiles from low approaches (one descent and one ascent on each) or takeoff and landing (single ascent or descent) occurring 0.6-6.2 h after sunset (Table 1). The low approaches had minimum altitudes ranging from 34-82 $\mathrm{m}$ above ground level. The four landings and one takeoff at Ellington Field in southeast Houston provided vertical profiles to ground level. Emissions of $\mathrm{NO}_{\mathrm{x}}$ were concentrated within the urban boundary and the industrial areas in the south of the domain, while the strongest BVOC emissions 
Table 1. Nighttime vertical profiles during TexAQS 2006.

\begin{tabular}{llllll}
\hline Flight & Airfield & $\begin{array}{l}\text { Hours after } \\
\text { Sunset }\end{array}$ & $\begin{array}{l}\text { Minimum } \\
\text { Altitude (m) }\end{array}$ & $\begin{array}{l}\text { Wind } \\
\text { Direction }\end{array}$ & $\begin{array}{l}\text { NBL } \\
\text { Depth (m) }\end{array}$ \\
\hline 29 Sep & Hooks & 0.55 & 52 & SE & 400 \\
& Hobby & 0.83 & 36 & ESE & 200 \\
& Bush & 1.36 & 34 & SE & 250 \\
& Ellington & 2.04 & 0 & ESE & 310 \\
\hline \multirow{2}{*}{ Oct } & Victoria & 2.00 & 58 & ESE & 120 \\
& Hooks & 2.59 & 82 & SSE & 130 \\
& Hobby & 2.78 & 66 & SE & 130 \\
& Ellington & 4.05 & 0 & SE & 110 \\
\hline \multirow{2}{*}{$10-11$ Oct } & Bush & 5.71 & 58 & NW & 380 \\
& Hobby & 5.89 & 65 & NW & 380 \\
& Ellington & 6.12 & 0 & WNW & 430 \\
\hline \multirow{2}{*}{ O1-12 Oct } & Ellington & 1.48 & 0 & S & 160 \\
& Hooks & 2.19 & 73 & S & 125 \\
& Hobby & 2.44 & 67 & S & 135 \\
& Sugarland & 2.87 & 53 & S & 100 \\
& Lone Star & 5.73 & 61 & S & 125 \\
& Bush & 6.00 & 55 & S & 200 \\
& Ellington & 6.22 & 0 & S & 100 \\
\hline & & & & & \\
\hline
\end{tabular}

were north of Houston. In three of the four night flights (29 September, 8 October, 11-12 October), early evening and nighttime flow was generally south to north across the urban area, carrying urban emissions into the forested areas, while on 10-11 October, flow was from the northwest, carrying $\mathrm{BVOC}$ emissions into the $\mathrm{NO}_{\mathrm{x}}$-rich urban area. In the former case, the $\mathrm{NO}_{\mathrm{x}}$ emissions transported north would provide a continuous source of $\mathrm{NO}_{3}$ oxidant for locally emitted BVOCs during nighttime transport. In the latter case, the oxidation products (including organic aerosol) would be apparent within the urban area, though the BVOCs themselves would likely be too short lived to survive transport. Observed BVOCs in this case would most likely arise from local emissions (which are non-zero) within the urban area. This section describes three distinct cases from the 8 October, 10-11 October and 11-12 October flights. The 29 September flight was similar to October 8, but has not been illustrated specifically with a case study below, in part because it did not extend as far in time beyond sunset as the other flights. The selected cases have been chosen subjectively as best illustrations of rapid nighttime chemistry, BVOC emission and oxidation, aerosol production or all three. None of the selected cases is inconsistent with the average characteristics of the vertical profiles (see Sects. 3.4 and 4).

\subsection{Case 1: $\mathrm{NO}_{\mathrm{x}}$-rich air mass advecting north in early evening}

The 8 October flight was a day-into-night flight $(2.6 \mathrm{~h}$ before to $4.1 \mathrm{~h}$ after sunset) with southeasterly winds at surface level in early evening that transported urban emissions from Houston northward. Figure 2 shows a map of the latter portions (2.4-4.1 h after sunset) of this flight. Figure $2 \mathrm{~b}$ shows potential temperature, $\Theta$, from which the static stability of the atmosphere can be determined, and nitrate radical production rate from the reaction of $\mathrm{NO}_{2}$ with $\mathrm{O}_{3}, P\left(\mathrm{NO}_{3}\right)$ (expressed in $\mathrm{ppbv} \mathrm{h}^{-1}$ ) for the profiles in panel A.

$P\left(\mathrm{NO}_{3}\right)=k\left[\mathrm{O}_{3}\right]\left[\mathrm{NO}_{2}\right]$

Here $k$ is the rate coefficient for reaction of $\mathrm{NO}_{2}$ with $\mathrm{O}_{3}$ (Atkinson et al., 2004) and square brackets indicate number densities. The NBL, taken as the top of the stable region (i.e., steeply increasing $\Theta$ with altitude), was relatively consistent at approximately $120 \mathrm{~m}$ (Table 1 ), although the height through which surface level pollutants were strongly mixed was higher than this level in the approach to Hooks airfield on the downwind side of Houston. The strong gradient in $\Theta$ near the surface on landing at Ellington Field indicates the presence of a shallow surface layer (Brown et al., 2007b) not penetrated on the low approaches. (Despite the presence of a surface layer, the observations described here clearly show nighttime mixing of pollutants to altitudes greater than a few tens of meters.) At altitudes near or below the top of the NBL, there was a steep increase in $P\left(\mathrm{NO}_{3}\right)$, indicating that surface level emissions of $\mathrm{NO}_{\mathrm{x}}$, contained within the shallow NBL, provide a large source of nitrate radicals. Values for $P\left(\mathrm{NO}_{3}\right)$ ranged from 1 to $2.8 \mathrm{ppbvh}^{-1}$, which are large for this radical (Brown and Stutz, 2012) and comparable to or larger than typical midday $\mathrm{OH}$ radical production rates during summer (e.g., Young et al., 2012). 

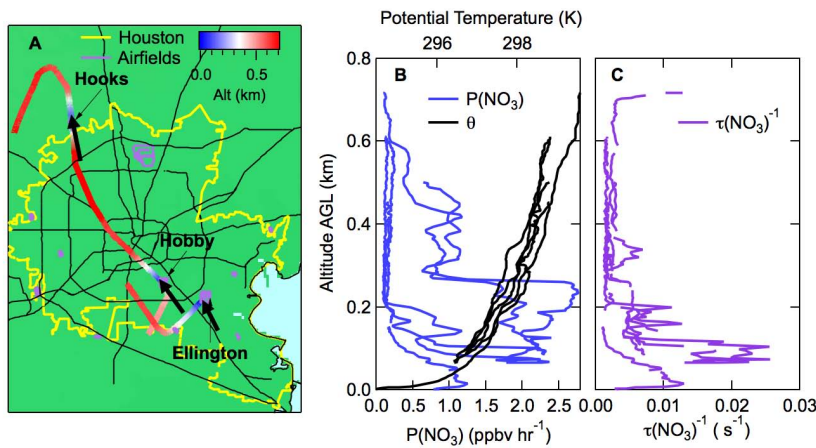

Fig. 2. (A) Selected portions of the P-3 flight track from 8 October 2006 overlaid on a map of the Houston area and color coded by altitude. Black arrows indicate wind direction and relative speed. The selected flight track includes low approaches to Hooks and Hobby, followed by landing at Ellington after an extended level leg (level portion not shown). (B) Vertical profiles of potential temperature (top axis) and $P\left(\mathrm{NO}_{3}\right)$ (bottom axis, see text) for all five vertical profiles (four from the low approaches, one from landing). (C) Inverse steady state $\mathrm{NO}_{3}$ lifetime, $\tau\left(\mathrm{NO}_{3}\right)^{-1}$ (see text).

Shown in Fig. $2 \mathrm{c}$ is the $\mathrm{NO}_{3}$ inverse steady-state lifetime, $\tau\left(\mathrm{NO}_{3}\right)^{-1}$, the ratio of the $\mathrm{NO}_{3}$ production rate to its mixing ratio.

$\tau\left(\mathrm{NO}_{3}\right)^{-1}=P\left(\mathrm{NO}_{3}\right) / \mathrm{NO}_{3}$

This quantity has units of inverse time $\left(\mathrm{s}^{-1}\right)$ and is a common measure of apparent $\mathrm{NO}_{3}$ reactivity, or first-order loss rate coefficient for $\mathrm{NO}_{3}$ (Platt et al., 1984; Geyer and Platt, 2002; Brown et al., 2003). The figure shows that $\tau\left(\mathrm{NO}_{3}\right)^{-1}$ was consistently enhanced at low altitude within the NBL relative to the overlying residual layer. This enhancement in apparent reactivity may be due to reactions of $\mathrm{NO}_{3}$ with reactive VOCs, an increased rate of $\mathrm{N}_{2} \mathrm{O}_{5}$ heterogeneous uptake to aerosol, or a failure of the steady state approximation for production and loss of $\mathrm{NO}_{3}$ (Brown et al., 2003). As the later discussion will show, however, a major component of this low altitude reactivity enhancement is loss of $\mathrm{NO}_{3}$ through reactions with biogenic VOC in the NBL.

The surface-level air mass transported north out of Houston on 8 October contained large $\mathrm{NO}_{\mathrm{x}}$ mixing ratios that influence nighttime biogenic VOC oxidation. Figure 3 shows an expanded view of the vertical profile at Hooks airfield, approximately $2.6 \mathrm{~h}$ after sunset. Panel A shows the potential temperature profile (top axis), which had discontinuous gradients with altitude at approximately 350 and $130 \mathrm{~m}$, with the latter likely representing the NBL and the former associated with an intermediate layer. Large increases in anthropogenic pollution were evident below $280 \mathrm{~m}$ from the $\mathrm{NO}_{2}$ profile and the associated titration of $\mathrm{O}_{3}$ (panel $\mathrm{B}$ ) and large mixing ratios of $\mathrm{NO}_{3}$ and $\mathrm{N}_{2} \mathrm{O}_{5}$ (panel $\mathrm{A}$ ). The strong anticorrelation between $\mathrm{NO}_{2}$ and $\mathrm{O}_{3}$, especially below $280 \mathrm{~m}$, is clear evidence for the influence of nighttime chemistry since photochemistry normally leads to positive correlations be-

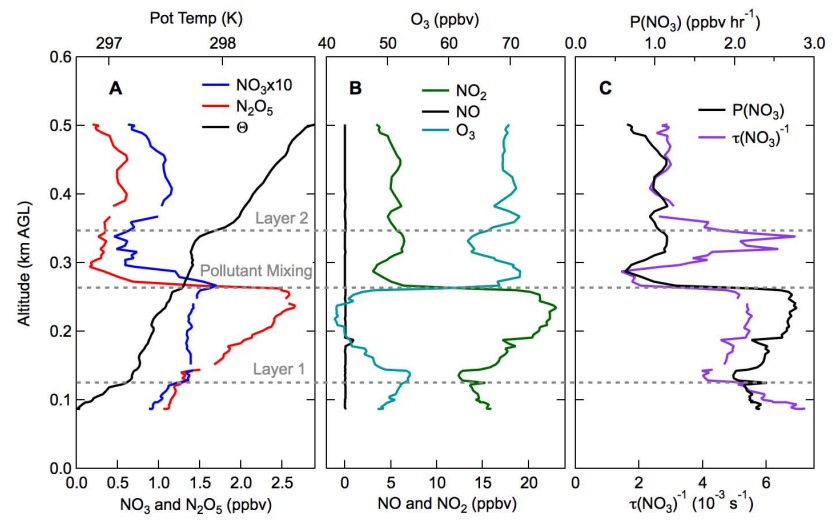

Fig. 3. Vertical profiles: (A) mixing ratios of $\mathrm{NO}_{3}(\times 10$ to make it visible) and $\mathrm{N}_{2} \mathrm{O}_{5}$ (bottom axis) and potential temperature (top axis); (B) mixing ratios of $\mathrm{NO}$ and $\mathrm{NO}_{2}$ (bottom axis) and $\mathrm{O}_{3}$ (top axis); (C) $\mathrm{NO}_{3}$ reactivity, measured as $\tau\left(\mathrm{NO}_{3}\right)^{-1}$ (bottom axis) and production rate, $P\left(\mathrm{NO}_{3}\right)$ (top axis). Data are for descent to Hooks on 8 October, 09:33 local time. Grey dashed lines and labels indicate altitudes of layers in the potential temperature profile and in the observed mixing of pollutants (see text).

tween $\mathrm{O}_{3}$ and reactive nitrogen, while nighttime chemistry leads to an anticorrelation (Brown et al., 2006). A plot of $\mathrm{O}_{3}$ against $\mathrm{NO}_{2}$ within this altitude range (not shown) has a slope of -1.56 and a correlation coefficient, $r^{2}=0.97$, consistent with a slightly aged plume in which $\mathrm{O}_{3}$ had been consumed by its rapid reaction with emitted $\mathrm{NO}$ and further consumed by its slower reaction with $\mathrm{NO}_{2}$ that produces both $\mathrm{NO}_{3}$ and $\mathrm{N}_{2} \mathrm{O}_{5}$ (Brown et al., 2006). The ratio of $\mathrm{NO}_{\mathrm{x}}$ to $\mathrm{NO}_{\mathrm{y}}$ (also not shown) shows an abrupt transition at $280 \mathrm{~m}$, with values of $0.65 \pm 0.03(1 \sigma)$ and $0.42 \pm 0.04$ below and above this altitude, respectively, implying more recent $\mathrm{NO}_{\mathrm{x}}$ emissions in the lower altitude air mass. The transition in $\mathrm{NO}_{\mathrm{x}}$ to $\mathrm{NO}_{\mathrm{y}}$ was present at the same altitude on both ascent and descent, demonstrating that is was due to vertical, rather than horizontal, variation during the low approach.

The nitrate radical production rate, $P\left(\mathrm{NO}_{3}\right)$, in Fig. $3 \mathrm{c}$ was strongly enhanced below $280 \mathrm{~m}$, varying from 2.0 $2.8 \mathrm{ppbv} \mathrm{h}^{-1}$. As the air mass moves north beyond the Hooks airfield, it would enter a region with a much larger emission potential for monoterpenes (see Fig. 1), which would undergo rapid and nearly exclusive oxidation with nitrate radicals. The lifetime of $\alpha$-pinene with respect to oxidation by $\mathrm{O}_{3}(47 \pm 4$ ppbv below $280 \mathrm{~m})$ was $2.9 \mathrm{~h}$, while its lifetime against oxidation by $\mathrm{NO}_{3}(127 \pm 17 \mathrm{pptv})$ was $0.9 \mathrm{~min}$. The lifetime for $\beta$-pinene would be $16.5 \mathrm{~h}$ and $2.2 \mathrm{~min}$ against $\mathrm{O}_{3}$ and $\mathrm{NO}_{3}$, respectively (Atkinson and Arey, 2003). The PTRMS measured no enhancement in biogenic VOCs above its detection limit within this vertical profile (no WAS samples taken), potentially due to their short lifetime in this air mass. However, biogenic VOCs were present consistently on other vertical profiles, as described below. 
Aerosol organic mass was also enhanced at low altitude, as the aerosol composition data in Fig. 4 shows. Below $280 \mathrm{~m}$, organic aerosol increased slightly to lower altitude, with a somewhat steeper increase below the NBL height of $130 \mathrm{~m}$ (single data point in the AMS at its time resolution). Panels $\mathrm{A}$ and $\mathrm{B}$ show that there were increases in both organic and nitrate aerosol mass, but not in sulfate or ammonium, below $280 \mathrm{~m}$. The relative changes in mass loading of different aerosol components with altitude were small in this example compared to others (see below) and could be subject to artifacts such as AMS collection efficiency (Middlebrook et al., 2012). Ratios of different components are less subject to artifacts and are more compelling. The ratio of sulfate to organic (panel B, top axis) decreased below $280 \mathrm{~m}$, while the ratio of nitrate to organic (panel $\mathrm{B}$, bottom axis) increased below $280 \mathrm{~m}$, but then decreased again below the NBL height. These observations are qualitatively consistent with a photochemically generated background of sulfate, nitrate and organic aerosol superimposed with a nighttime component to nitrate and organic aerosol mass that was enhanced at low altitude. Acetonitrile, an indicator for biomass burning, was variable on this profile and modestly enhanced at low altitude, but it did not correlate well with other tracers of biomass burning, such as black carbon. Thus, it is possible that the organic aerosol on this profile had some influence from biomass burning.

The presence of enhanced nitrate mass may be consistent with an increased organic aerosol mass since $\mathrm{NO}_{3}$ reacts with monoterpenes to produce organic nitrates in high yields (Hallquist et al., 1999), and these nitrate products are thought to be associated with the condensable material that forms SOA from these reactions (Fry et al., 2009, 2011). Aerosol nitrate may also arise from inorganic nitrate production through $\mathrm{N}_{2} \mathrm{O}_{5}$ hydrolysis and partitioning of gas phase nitric acid, $\mathrm{HNO}_{3}$, with gas phase ammonia, $\mathrm{NH}_{3}$, to aerosol ammonium nitrate. Mixing ratios of $\mathrm{NH}_{3}$ increased consistently in the NBL relative to the residual layer in all vertical profiles. For this profile, $\mathrm{HNO}_{3}$ had a concurrent, but larger, decrease in mixing ratio compared to the increase in aerosol nitrate and the ratio of measured aerosol ammonium to that calculated from aerosol sulfate and nitrate as their ammonium salts was $1.1 \pm 0.1$. The ratio of $\mathrm{m} / z 30$ to $\mathrm{m} / \mathrm{z} 46$ in the AMS mass spectra for this missed approach at Hooks was $3.6 \pm 0.5$, which is slightly higher than measured during calibration with pure ammonium nitrate particles $(2.3 \pm 0.3)$. While the higher ratio does not preclude ammonium nitrate in the aerosol phase, it does indicate the presence of either an organic nitrate, an oxygenated organic fragment, an amine, or another cation with inorganic nitrate (Marcolli et al., 2006; Farmer et al., 2010). On the basis of the available data from these profiles, it is difficult to assign the source of the lowaltitude nitrate aerosol enhancement to either the organic or the inorganic nighttime pathway.

The observed organic aerosol enhancements on this profile likely have contributions from both primary emissions (i.e.,

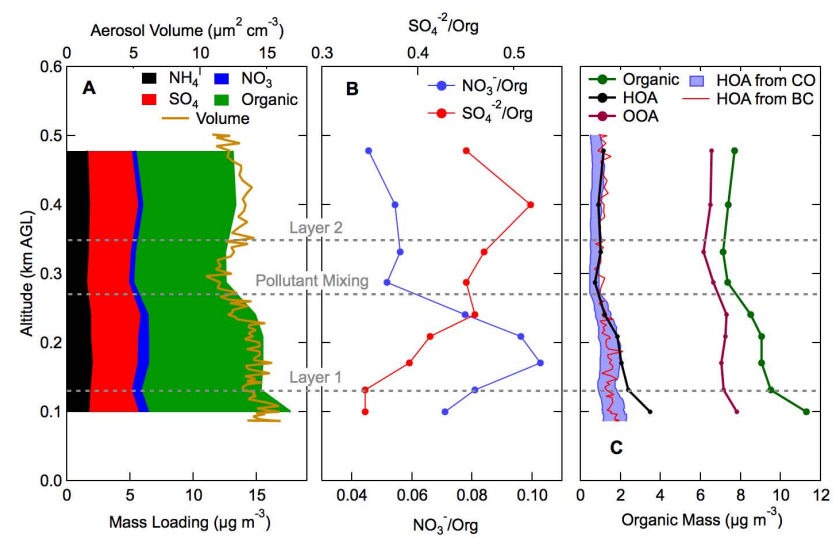

Fig. 4. Vertical profile of (A) Aerosol ammonium, sulfate, nitrate and organic, stacked together as a sum (bottom axis) and aerosol volume (top axis); (B) ratio of aerosol nitrate to organic (bottom axis) and sulfate to organic (top axis); and (C) organic aerosol mass compared to AMS estimates for OOA (secondary aerosol) and HOA (primary aerosol), and primary aerosol mass loadings estimated from carbon monoxide (CO) and black carbon (BC) (see text for description). Data are for descent to Hooks on 8 October, 09:33 local time. Grey dashed lines indicate the same layer structure shown in Fig. 3.

organic particulate matter directly emitted from a combustion source) and secondary growth. Figure $4 \mathrm{c}$ shows the vertical profile in organic mass relative to three estimates of mass loadings due to primary emissions and one due to secondary organic aerosol. Results of an iterative multivariate regression analysis of the AMS data are shown for oxygenated organic aerosol (OOA) and for hydrocarbon like organic aerosol (HOA), interpretable as secondary organic aerosol and primary organic aerosol (POA), respectively (Zhang et al., 2005a, b). Most of the organic aerosol increase immediately below $280 \mathrm{~m}$, near the top of the layer with high $\mathrm{NO}_{\mathrm{x}}$ mixing ratios, arises from the OOA factor (secondary source), while most (approximately $60 \%$ ) of the sharp increase at the lowest altitude sampled arises from the HOA factor (attributable to primary emissions). The HOA factor here is likely an upper limit to actual POA mass, however, due to the potential for slightly oxygenated ions to contribute to masses normally attributed to HOA (Bahreini et al., 2012; Kroll et al., 2012). Also shown in Fig. 4c are parameterizations for POA mass based on the HOA ratio to either carbon monoxide $(\mathrm{CO})$ or black carbon $(\mathrm{BC})$. The ratio of HOA to $\mathrm{CO}$ falls in the range of $5-10 \mu \mathrm{g} \mathrm{m}^{-3} / \mathrm{ppmv} \mathrm{CO}$ for urban regions (de Gouw and Jimenez, 2009). Similarly, the ratio of HOA to black carbon mass has been estimated from urban data as 1.3 to 1.4 (Zhang et al., 2005b; Aiken et al., 2009), and this HOA parameterization also appears in Fig. 4c. These two parameterizations suggest that approximately $25 \%$ of the low-altitude organic aerosol enhancement sampled in the Hooks profile is attributable to primary organic aerosol, and that as much as $75 \%$ of the organic aerosol in this profile 

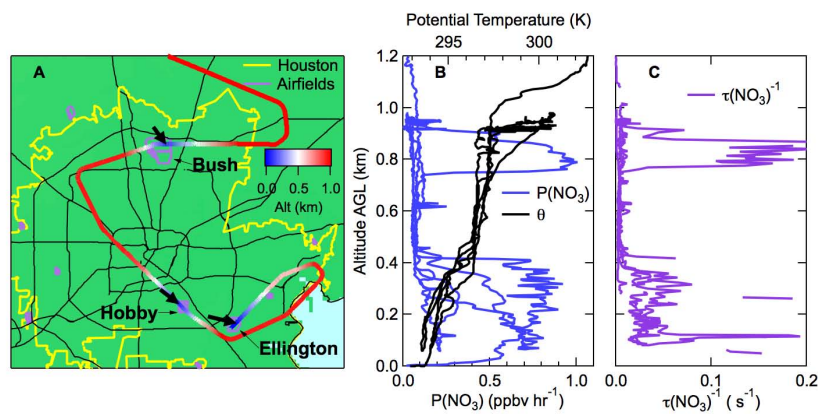

Fig. 5. (A) Same as Fig. 2, except for the latter portion of the P-3 flight track on 10-11 October.

is due to secondary processes. Like aerosol nitrate from gas phase $\mathrm{HNO}_{3}$, there is a potential for some of the gas phase organic acid species to partition to the aerosol phase in the NBL where the $\mathrm{NH}_{3}$ mixing ratios were enhanced. Yet, a combination of factors, including a large nighttime radical source, the potential for nighttime monoterpene emissions, the anticorrelation of nitrogen oxides and ozone, and organic aerosol enhancements in excess of that predicted to arise from primary emissions, suggests a nighttime secondary organic aerosol source for this profile over Hooks airfield. Due to the large $\mathrm{NO}_{\mathrm{x}}$ mixing ratios, rapid $\mathrm{NO}_{3}$ production rate and large relative oxidation of biogenic VOCs by $\mathrm{NO}_{3}$ relative to $\mathrm{O}_{3}$, the secondary aerosol source due to $\mathrm{NO}_{3}$-monoterpene reactions should increase substantially during northward transport of this air mass into the forested region.

\subsection{Case 2: BVOC rich air mass advecting south}

The 10-11 October flight executed a series of vertical profiles near the urban area just after midnight local time. The flight took place immediately following a frontal passage, with winds from the north or northwest behind the front, transporting the stronger biogenic emissions into the urban area. Background levels of pollutants were lower within the Houston urban area on this flight relative to others.

Figure 5 shows the P-3 track for the last leg of this flight. The profiles over Hobby and Ellington airfields were on the downwind side of the urban area, while the profiles over Bush airfield were upwind. The NBL was well developed, relatively deep, and clearly defined near $400 \mathrm{~m}$ in the potential temperature for all five profiles (two low approaches and one landing after dark). The discontinuity in the potential temperature gradient at $1.1 \mathrm{~km}$ likely indicates the top of the residual daytime boundary layer, although the actual top of the residual layer may have been above the sampled altitude on these profiles. Urban emissions were concentrated within the NBL, as shown by the vertical distribution of $P\left(\mathrm{NO}_{3}\right)$ in Fig. 5b. During the approach to landing at Ellington Field, the aircraft transected a plume with larger $P\left(\mathrm{NO}_{3}\right)$ between $700-900 \mathrm{~m}$ that was directly downwind of the Houston Ship

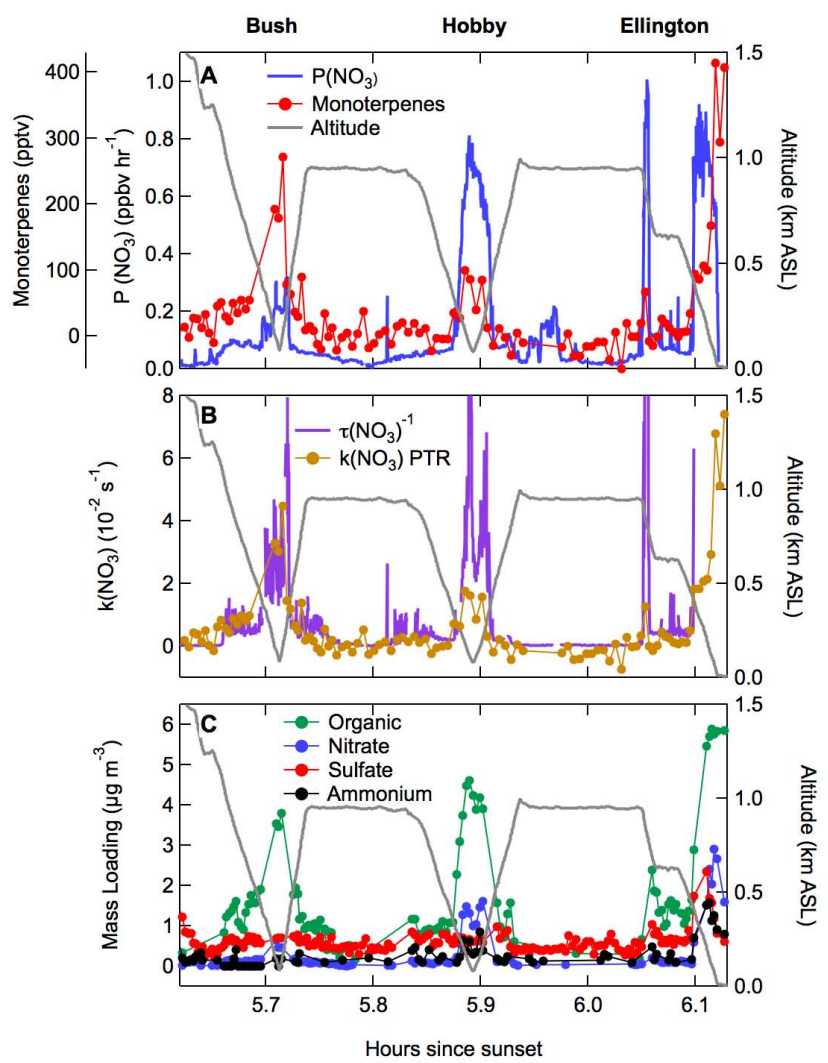

Fig. 6. Time series (plotted as hours since sunset) from five vertical profiles between midnight and 01:00 local time on 11 October showing (A) nitrate radical production rate, $P\left(\mathrm{NO}_{3}\right)$ (left axis), monoterpene mixing ratio (far left axis) and aircraft altitude (right axis); (B) inverse $\mathrm{NO}_{3}$ lifetime, $\tau\left(\mathrm{NO}_{3}\right)^{-1}$, and first-order $\mathrm{NO}_{3}$ loss rate coefficient, $k\left(\mathrm{NO}_{3}\right)$ from PTRMS measurements of biogenic VOCs (see text), plotted together against the left axis; (C) mass loading of aerosol organic, nitrate, sulfate and ammonium from the AMS. Aircraft altitude is plotted against the right axis for reference in (B) and (C).

Channel. Analysis of such lofted nighttime plumes is not the subject of this paper but has been discussed previously (Brown et al., 2011, 2012).

Figure 6 shows the time series for these two low approaches and landing. The figure shows only the monoterpene measurements from the PTRMS, although isoprene was also enhanced during these profiles (Table 2). Measurements from discrete canister samples for these profiles corroborated the presence of monoterpenes, although $\alpha$-pinene was the only monoterpene reported for the canister samples. The mixing ratio of $\alpha$-pinene from the canister sample was approximately $20 \%$ of the summed monoterpenes from the PTRMS (Table 2). Isoprene was also considerably larger in the PTR measurements than in the canister samples, although the canister samples clearly show that isoprene was present below the NBL on the vertical profiles. Both biogenic VOCs strongly peaked at low altitude on all five vertical profiles in 
Table 2. Biogenic VOC, $\mathrm{NO}_{3}$ and $\mathrm{O}_{3}$ mixing ratios, first-order VOC loss rate coefficients with respect to both $\mathrm{NO}_{3}$ and $\mathrm{O}_{3}\left(k^{\prime}\left(\mathrm{NO}_{3}\right)\right.$, $k^{\prime}\left(\mathrm{O}_{3}\right)$ ), and total VOC loss rates within the nocturnal boundary layer for six airfield approaches on 11 October and 12 October. The VOC mixing ratios are shown for both PTR and WAS samples, where WAS monoterpenes refers to $\alpha$-pinene alone. Oxidation rates are calculated for the mixing ratios determined for each instrument $\left(R_{\mathrm{PTR}}, R_{\mathrm{WAS}}\right)$.

\begin{tabular}{|c|c|c|c|c|c|c|c|c|c|}
\hline $\begin{array}{l}\text { Oct } \\
\text { Date }\end{array}$ & Airfield & $\begin{array}{r}\mathrm{NO}_{3} \\
\mathrm{ppt}\end{array}$ & $\begin{array}{r}\mathrm{O}_{3} \\
\mathrm{ppb}\end{array}$ & $\begin{array}{r}\text { PTR } \\
\text { ppt }\end{array}$ & $\begin{array}{r}\text { WAS } \\
\text { ppt }\end{array}$ & $\begin{array}{r}k^{\prime}\left(\mathrm{NO}_{3}\right) \\
\mathrm{h}^{-1}\end{array}$ & $\begin{array}{r}k^{\prime}\left(\mathrm{O}_{3}\right) \\
\mathrm{h}^{-1}\end{array}$ & $\begin{array}{r}R_{\mathrm{PTR}} \\
\mathrm{ppb} \mathrm{h}^{-1}\end{array}$ & $\begin{array}{r}R_{\mathrm{WAS}} \\
\mathrm{ppbh}^{-1}\end{array}$ \\
\hline \multicolumn{10}{|c|}{ Total monoterpenes (PTRMS) and $\alpha$-pinene (WAS) } \\
\hline \multirow[t]{3}{*}{11} & Bush & 1.8 & 31 & 180 & 34 & 1 & 0.23 & 0.22 & 0.042 \\
\hline & Hobby & 5.4 & 23 & 67 & 11.9 & 3 & 0.17 & 0.21 & 0.038 \\
\hline & Ellington & 0.5 & 15 & 197 & ND & 0.28 & 0.11 & 0.08 & \\
\hline \multirow[t]{3}{*}{12} & Lone Star & 5.0 & 6.0 & 276 & 59 & 2.8 & 0.05 & 0.78 & 0.16 \\
\hline & Bush & 83 & 51 & ND & ND & 46.3 & 0.4 & 1.0 & \\
\hline & Ellington & 34 & 47 & 62 & ND & 19.0 & 0.4 & 1.2 & \\
\hline \multicolumn{10}{|c|}{ Isoprene (PTRMS and WAS) } \\
\hline \multirow[t]{3}{*}{11} & Bush & 1.8 & 31 & 156 & 82 & 0.11 & 0.04 & 0.02 & 0.012 \\
\hline & Hobby & 5.4 & 23 & 150 & 68 & 0.33 & 0.03 & 0.05 & 0.025 \\
\hline & Ellington & 0.5 & 15 & 262 & ND & 0.03 & 0.018 & 0.013 & \\
\hline \multirow[t]{3}{*}{12} & Lone Star & 5 & 6 & 358 & 57 & 0.3 & 0.007 & 0.1 & 0.2 \\
\hline & Bush & 83 & 51 & 98 & 2 & 5.0 & 0.1 & 0.5 & 0.010 \\
\hline & Ellington & 34 & 47 & 91 & 5 & 2.1 & 0.1 & 0.2 & 0.011 \\
\hline
\end{tabular}

$\mathrm{ND}=$ No Data

Fig. 6. Nitrate radical production rates, $P\left(\mathrm{NO}_{3}\right)$, also peaked at low altitude, coincident with the BVOC enhancements, and consistent with trapping of both $\mathrm{NO}_{\mathrm{x}}$ pollution and $\mathrm{VOC}$ emissions within the shallow NBL. The co-location of the enhancements in these constituents implies that the nitrate radical rapidly oxidized biogenic VOCs within the NBL.

Biogenic VOC mixing ratios from the PTRMS, particularly monoterpenes, imply that a large fraction of $\mathrm{NO}_{3}$ reacts with biogenic VOCs at low altitude. Figure $6 \mathrm{~b}$ compares the $\mathrm{NO}_{3}$ inverse steady state lifetime, $\tau\left(\mathrm{NO}_{3}\right)^{-1}$ from Eq. (2) with the $\mathrm{NO}_{3}$ first order loss rate coefficient, $k\left(\mathrm{NO}_{3}\right)$, calculated from the PTRMS BVOCs.

$k\left(\mathrm{NO}_{3}\right)=\sum_{i}\left[\mathrm{VOC}_{i}\right]=k_{\text {isop }}[\mathrm{Isop}]+k_{\mathrm{mono}}[$ Monoterp $]$

The first order loss rate coefficient is the sum of the products of the bimolecular rate coefficient for the reaction of $\mathrm{NO}_{3}$ with each VOC and the concentration of that VOC. In Fig. 6 , there are only two VOCs in the sum. The rate coefficient for reaction of $\mathrm{NO}_{3}$ with monoterpenes has been taken as that for $\alpha$-pinene, which lies approximately in the middle of the range from $\beta$-pinene (lowest) to limonene (highest) (Atkinson and Arey, 2003). The $\tau\left(\mathrm{NO}_{3}\right)^{-1}$ peaked sharply underneath the NBL and was of the same order of magnitude as the $k\left(\mathrm{NO}_{3}\right)$ determined from the PTRMS BVOCs. The low approach at Bush, $25 \mathrm{~km}$ north of central Houston and closest to the strong biogenic VOC sources, shows quantitative agreement between the two independently determined rate coefficients. For the second low approach at
Hobby, $\tau\left(\mathrm{NO}_{3}\right)^{-1}$ exceeded $k\left(\mathrm{NO}_{3}\right)$ by approximately a factor of two, suggesting that approximately half of the $\mathrm{NO}_{3}$ reactivity was due to the two VOC classes. The uncertainties in $\tau\left(\mathrm{NO}_{3}\right)^{-1}$ and $k\left(\mathrm{NO}_{3}\right)$ are $20 \%$ each, based on the stated uncertainty for $\mathrm{NO}_{3}$ (the dominant uncertainty for $\left.\tau\left(\mathrm{NO}_{3}\right)^{-1}\right)$ and for the VOC measurements by the PTRMS (Parrish et al., 2008; Brown et al., 2011). Reactions of $\mathrm{NO}_{3}$ with anthropogenic VOCs and $\mathrm{N}_{2} \mathrm{O}_{5}$ uptake to aerosol were also important processes during TexAQS 2006 night flights (Brown et al., 2011), although SOA formation from $\mathrm{NO}_{3}$ anthropogenic VOC reactions is likely to be small (Gong et al., 2005). The final profile at Ellington had too little $\mathrm{NO}_{3}$ to quantitatively determine $\tau\left(\mathrm{NO}_{3}\right)^{-1}$, but did have large mixing ratios of both isoprene and monoterpenes measured on the PTRMS near ground level on landing. As noted above, BVOC mixing ratios from the PTRMS were systematically larger than those from the WAS, particularly for isoprene. Thus, the derived $k\left(\mathrm{NO}_{3}\right)$ values are upper limits. Although the largest potential discrepancy between the instruments is for isoprene, the $k\left(\mathrm{NO}_{3}\right)$ are dominated by the monoterpenes, for which the WAS provides a lower limit, since only $\alpha$ pinene is reported.

As on 8 October, both nitrate and organic peaked sharply at low altitude, coincident with the BVOC and $P\left(\mathrm{NO}_{3}\right)$ peaks under the NBL. The principle difference between the 8 October and 10-11 October flights was the frontal passage that preceded the latter flight and led to a smaller aerosol background at all altitudes. Figure $6 \mathrm{c}$ shows the mass loading of aerosol ammonium, sulfate, nitrate and organic. The 


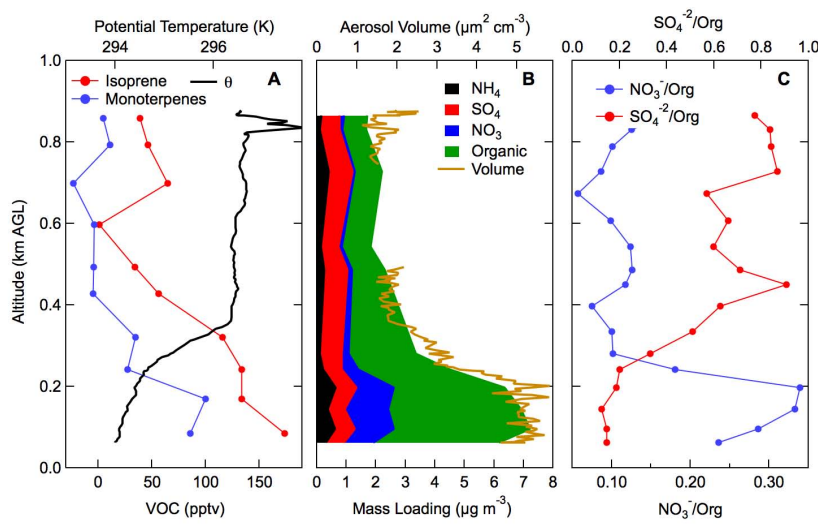

Fig. 7. Vertical profile from the descent to Hobby airfield on 11 October, just after midnight. (A) Mixing ratio of isoprene and monoterpenes (bottom axis) and potential temperature profile (top axis). (B) Mass loading of ammonium, sulfate, nitrate and organic from the AMS (bottom axis) and total aerosol volume (top axis). (C) Ratio of nitrate and sulfate to organic mass (bottom and top axes, respectively).

enhancements below the NBL height on 10-11 October thus stand out in starker contrast against the smaller background. The final profile at Ellington was notable in that it exhibited increases in all aerosol components, including sulfate and ammonium, whereas the other profiles principally show enhancements in organic and nitrate at low altitude. The reason for this difference is not clear, although Ellington was on the downwind side of large emission sources in the Houston Ship Channel on this descent. Prior aircraft transects downwind of large sulfur sources have shown evidence for direct emissions of sulfate aerosol (Brown et al., 2007a), although no definitive assignment is possible in this case.

Figure 7 shows the vertical profile from the descent to Hobby airfield on the downwind side of the urban area. The potential temperature profile in panel A shows a strongly stable NBL with a depth of $380 \mathrm{~m}$. Panel A also shows the vertical profile of biogenic VOCs from the PTRMS, with pronounced enhancements in the NBL. Panel B shows the aerosol mass loadings along with total aerosol volume from the particle-counting instrument (top axis). The relationship between the two depends on the aerosol density, which in turn depends on the relative amounts of organic and inorganic components, but varies over the range $1.25-1.75 \mathrm{~g} \mathrm{~cm}^{-3}$. Aerosol volume and mass were strongly enhanced in the NBL, but the mass enhancements were principally in nitrate and organic, with sulfate nearly constant throughout the profile. Panel C shows the ratio of sulfate and nitrate to organic, with the former strongly decreased and the latter strongly increased in the NBL. As with the example in Fig. 4 from the Hooks low approach on 8 October, nitrate aerosol showed a larger enhancement near the top of the NBL than near the bottom of the profile. However, unlike the Hooks profile, this aerosol nitrate enhancement was likely due to conden-

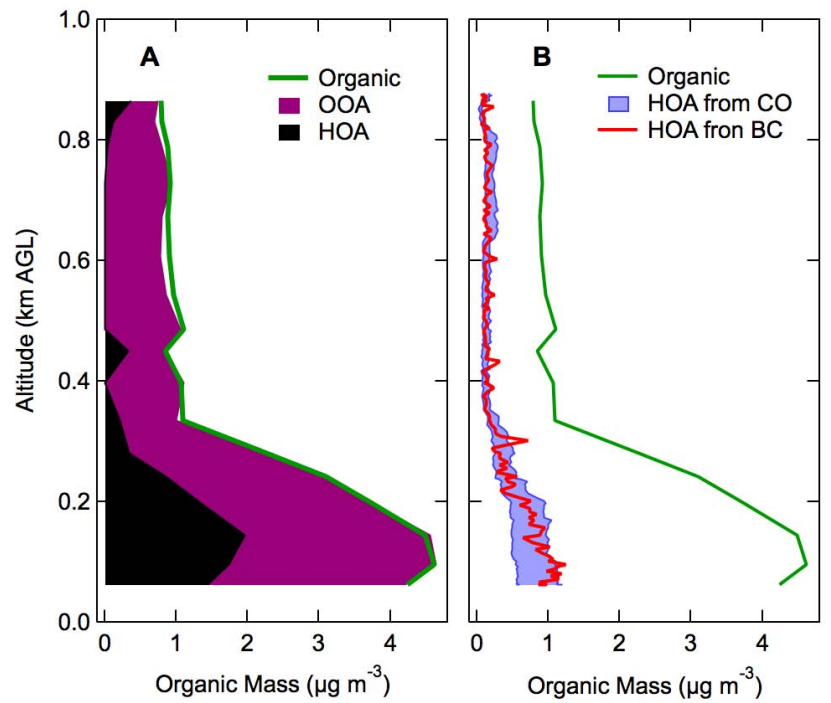

Fig. 8. Vertical profile from descent to Hobby airfield on 11 October showing (A) organic mass loading in comparison to OOA and HOA derived from the AMS; (B) organic mass loading compared to HOA derived from a parameterization against $\mathrm{CO}$ and black carbon $(\mathrm{BC})$ (see text).

sation of ammonium nitrate: there is a clear increase in the measured ammonium coincident with the increased aerosol nitrate, the concurrent increase in aerosol nitrate mass was comparable to a decrease in gas phase $\mathrm{HNO}_{3}$; and the ratio of $\mathrm{m} / \mathrm{z} 30$ to $\mathrm{m} / \mathrm{z} 46$ was $2.6 \pm 0.3$. The inorganic nitrate comes from nighttime chemistry through the heterogeneous hydrolysis of $\mathrm{N}_{2} \mathrm{O}_{5}$. Chemistry occurring in the NBL was attributable to a nighttime process, since $\mathrm{NO}_{2}$ and $\mathrm{O}_{3}$ were strongly anticorrelated (not shown) with a slope of -1.7 and a correlation coefficient $r^{2}>0.98$.

The source of the late night enhancement of organic aerosol within the NBL likely had contributions from both primary emissions and secondary processes, as in the preceding example. Figure $8 \mathrm{a}$ shows the vertical profile of oxygenated organic aerosol (OOA) and hydrocarbon-like organic aerosol (HOA) estimated from the AMS relative to total organic aerosol mass. The factor analysis suggests that approximately $45 \%$ of the organic aerosol enhancement (defined as the difference in mass loading within and above the NBL) is attributable to primary emissions (HOA), while $55 \%$ arises from a secondary source (OOA). Panel B shows the same comparison, but for HOA estimated from carbon monoxide (CO) and black carbon (BC), as described above. Based on these estimates, primary emissions would contribute approximately $17-21 \%$ of the organic aerosol enhancement in the NBL.

Figure 9 shows a plot of organic aerosol mass against $\mathrm{CO}$ for the low approach at Hobby on 11 October. The figure includes data from both the descent and ascent (vertical profiles from descent only shown in Fig. 7 and Fig. 8), and separates 


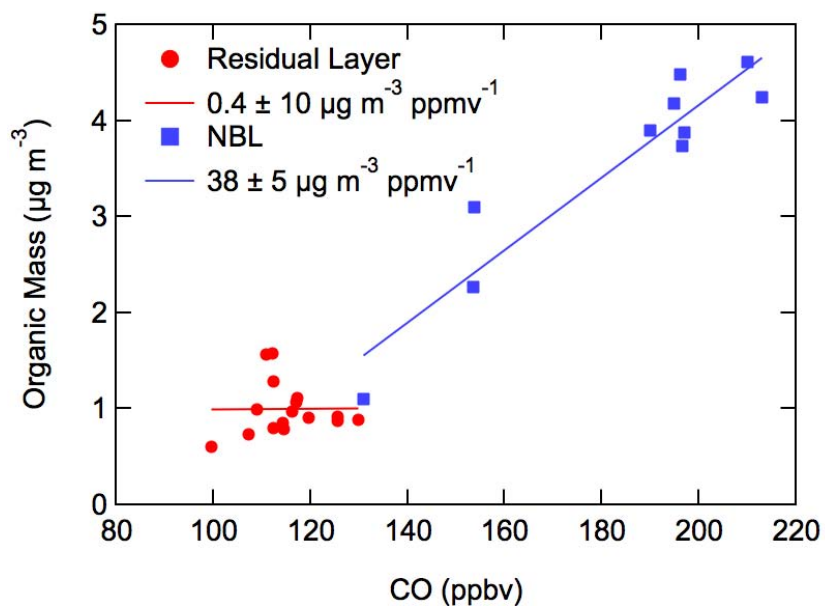

Fig. 9. Plot of organic aerosol mass $\left(\mu \mathrm{g} \mathrm{m}^{-3}\right)$ from the AMS against carbon monoxide (CO) in ppbv for the profile at Hobby airfield on 11 October shown in Fig. 7. Red and blue data points are for the residual and nocturnal boundary layers, respectively. Slopes of linear fits to each data set are shown in the legend.

data into those above and below the NBL height (see legend in figure). Because this flight occurred immediately following frontal passage, there was little aerosol mass from the previous day within the overlying residual layer, and a fit to the data gives essentially zero organic mass enhancement within this layer $\left(0.4 \pm 10 \mu \mathrm{g} \mathrm{m}^{-3}\right)$. The NBL, by contrast, exhibited a $38 \pm 5 \mu \mathrm{g} \mathrm{m}^{-3} / \mathrm{ppmv}$ CO. For POA in urban air, this ratio is $5-10 \mu \mathrm{g} \mathrm{m}^{-3} / \mathrm{ppmv} \mathrm{CO}$ (de Gouw and Jimenez, 2009). Because the residual layer was relatively clean on this date, the enhancement in OA above the POA estimation is strong evidence that SOA had formed in the NBL. At Bush, which is closer to the monoterpene source, the slope was slightly higher, $49 \pm 10 \mu \mathrm{g} \mathrm{m}^{-3} / \mathrm{ppmv} \mathrm{CO}$. The monoterpene mixing ratios were higher at Bush than at Hobby and the measured inverse lifetime of $\mathrm{NO}_{3}$ was more closely matched with the calculated reactivity of $\mathrm{NO}_{3}$ with monoterpenes at Bush compared to Hobby. These results are consistent with SOA formed from $\mathrm{NO}_{3}$ oxidation of monoterpenes as the monoterpene-rich air mass from the north advected to the southeast over the urban area. The slope of $\triangle \mathrm{OA} / \triangle \mathrm{CO}$ in the NBL in Fig. 9 is comparable to values determined for photochemical production of organic aerosol within urban areas in Texas, but smaller than those determined for organic aerosol production downwind of the VOC-rich sources of the industrial areas of the Houston Ship Channel (Bahreini et al., 2009). The model in Sect. 6 describes the relevant timescales and rates of OA production from the nighttime source relative to these observations.

The correlation with $\mathrm{CO}$ for nighttime generated aerosol would be expected if the aerosol production rate were strictly proportional to $\mathrm{NO}_{\mathrm{x}}$, the source for $\mathrm{NO}_{3}$. Proportionality to $\mathrm{CO}$ would not necessarily arise from an aerosol production that was dominated by BVOC emissions, unless both
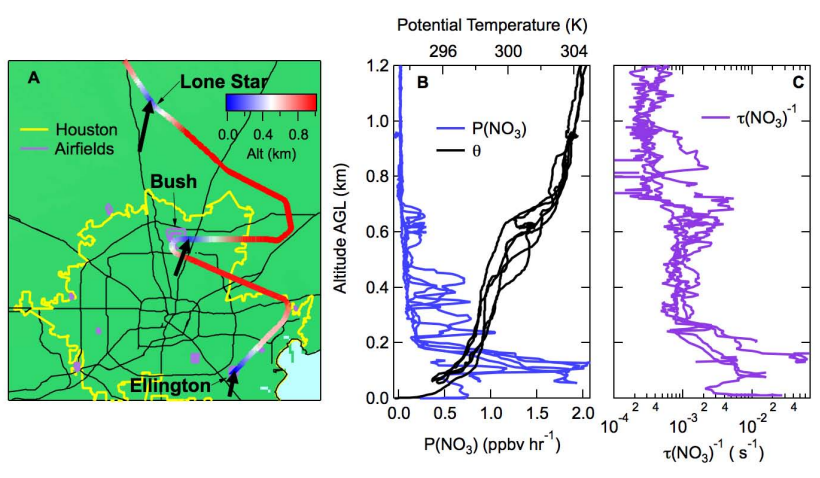

Fig. 10. Same as Fig. 2 except for the latter portion of the P-3 flight track on 11-12 October. Note that $\tau\left(\mathrm{NO}_{3}\right)^{-1}$ in $(\mathbf{C})$ is on a logarithmic scale to show the contrast between its large increase in the lowest layer and its small values at high altitude.

the BVOC and $\mathrm{CO}$ concentrations varied with height, as in the observations. Thus, the correlation with $\mathrm{CO}$ is largely a benchmark for comparison with the literature values for the magnitude of the OA source, rather than a statement about the mechanism for nighttime aerosol generation.

\subsection{Case 3: $\mathrm{NO}_{\mathrm{x}}$ rich air mass well north of urban area; local source}

The 12 October flight surveyed nighttime transport and chemistry of industrial emissions north out of Houston, and included a series of five vertical profiles, two low approaches and one landing, across the urban area after midnight and 5.7-6.2 $\mathrm{h}$ after sunset (Fig. 10). Winds were generally from the south-southwest carrying urban pollution north into the forested areas. The forward trajectory in Fig. 1 gives the scale of the overnight $(12 \mathrm{~h})$ transport distance beginning at sunset at $100 \mathrm{~m}$ altitude from Bush airfield. Overnight transport extended $110 \mathrm{~km}$ beyond the urban boundary and into the area of large monoterpene emissions. The south to north transport was similar to that of 8 October, but the 12 October flight differed in three respects. First, vertical profiles on the 12 October flight were much later at night. Second, the 12 October flight included a profile at Lone Star airfield, $65 \mathrm{~km}$ north of Houston where the BEIS3 inventory shows large monoterpene emission potential (Fig. 1). Finally, the flight was also likely influenced by biomass burning in some locations, including the low altitude approach to Lone Star, as well as by strong local anthropogenic emissions, as described further below. Thus, although this flight included a profile in the region most likely to have been influenced by nighttime biogenic VOC emissions and oxidation, the low altitude chemical composition of the air mass was likely influenced by multiple factors.

The NBL structure during the full set of profiles (Fig. 10) extended to just above $100 \mathrm{~m}$, with another layer near 700$800 \mathrm{~m}$. This altitude is relatively shallow for the top of the 

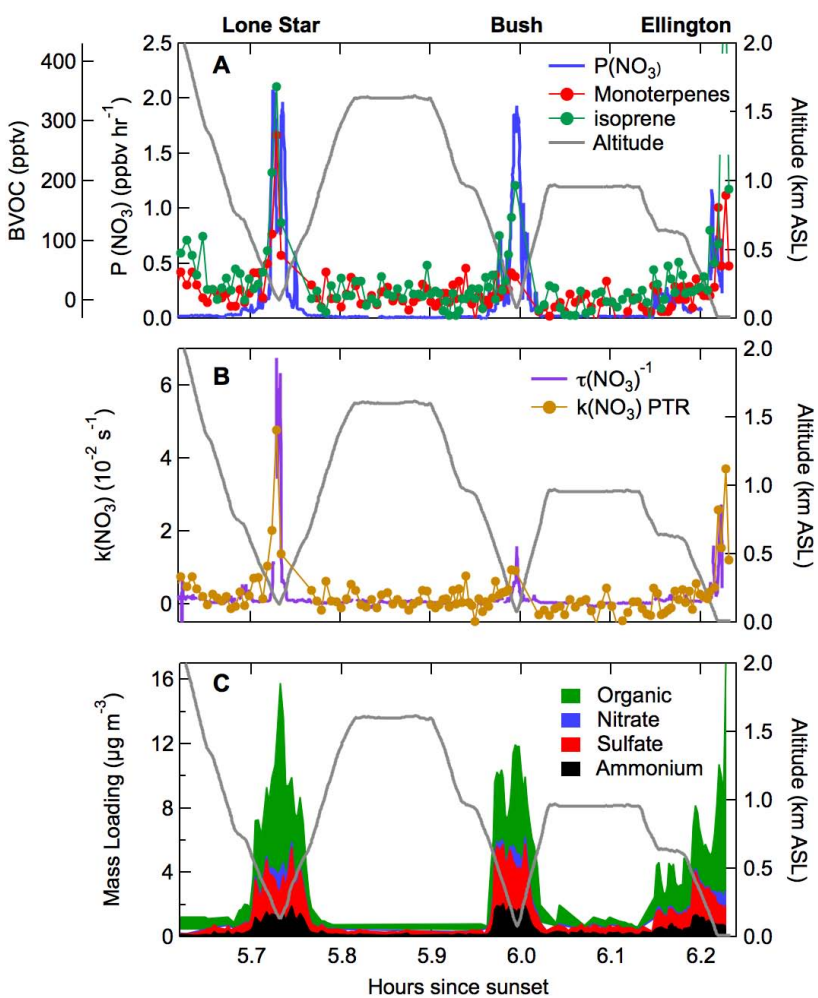

Fig. 11. Time series (plotted as hours since sunset) from five vertical profiles (airfields labeled at top of plot) between midnight and 01:00 local time on 12 October showing (A) nitrate radical production rate, $P\left(\mathrm{NO}_{3}\right)$ (left axis), monoterpene and isoprene mixing ratio (far left axis) and aircraft altitude (right axis); (B) inverse $\mathrm{NO}_{3}$ lifetime, $\tau\left(\mathrm{NO}_{3}\right)^{-1}$, and first-order $\mathrm{NO}_{3}$ loss rate coefficient, $k\left(\mathrm{NO}_{3}\right)$ from PTRMS measurements of biogenic VOCs (see text), plotted together against the left axis; (C) mass loading of aerosol organic, nitrate, sulfate and ammonium from the AMS. Aircraft altitude is plotted against the right axis for reference in $(\mathbf{B})$ and $(\mathbf{C})$.

residual boundary layer, but on this day it may have been influenced by a marine boundary layer structure from the nearby Gulf of Mexico under southerly flow. The potential temperature exhibited a steep gradient below $40 \mathrm{~m}$ on landing at Ellington, again characteristic of a shallow surface layer. There were several layers above the NBL with $P\left(\mathrm{NO}_{3}\right)$ up to $1 \mathrm{ppbv} \mathrm{h}^{-1}$, particularly for the approach to Bush, which was downwind of urban Houston and the Ship Channel. However, $P\left(\mathrm{NO}_{3}\right)$ within the NBL was consistently larger, to approximately $2 \mathrm{ppbvh}^{-1}$. Figure 10c shows $\tau\left(\mathrm{NO}_{3}\right)^{-1}$ on a logarithmic scale to capture the range of $\mathrm{NO}_{3}$ reactivity. The $\tau\left(\mathrm{NO}_{3}\right)^{-1}$ showed distinct steps associated with the transition from the NBL to the residual layer, and from the residual layer to the free troposphere.

Similar to the previous examples, Fig. 11 shows that $P\left(\mathrm{NO}_{3}\right)$, BVOCs and $\tau\left(\mathrm{NO}_{3}\right)^{-1}$ were all strongly enhanced together at low altitude in approaches to Lone Star, Bush and Ellington Field. The $\tau\left(\mathrm{NO}_{3}\right)^{-1}$ values were essentially equal to $k\left(\mathrm{NO}_{3}\right)$, derived from PTRMS BVOCs, implying that a

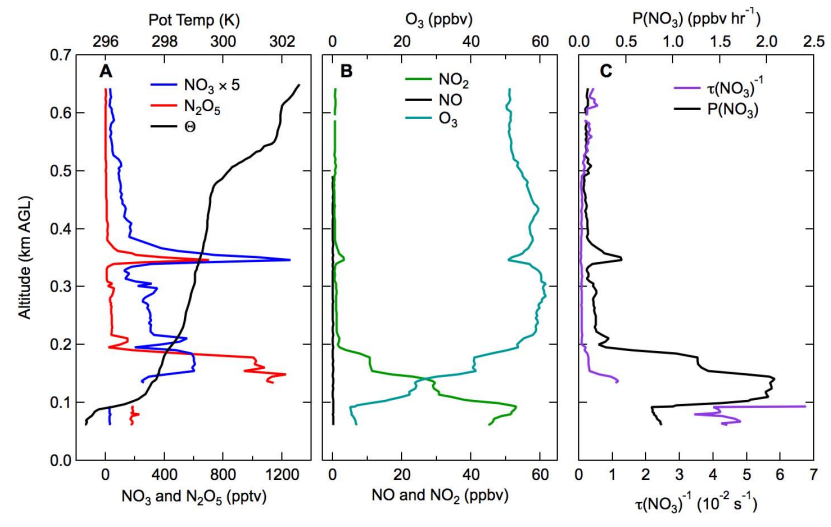

Fig. 12. Vertical profile of (A) mixing ratios of $\mathrm{NO}_{3}(\times 5$ to make it visible) and $\mathrm{N}_{2} \mathrm{O}_{5}$ (bottom axis) and potential temperature (top axis); (B) mixing ratios of $\mathrm{NO}$ and $\mathrm{NO}_{2}$ (bottom axis) and $\mathrm{O}_{3}$ (top axis); (C) $\mathrm{NO}_{3}$ reactivity, measured as $\tau\left(\mathrm{NO}_{3}\right)^{-1}$ (bottom axis), and production rate $P\left(\mathrm{NO}_{3}\right)$ (top axis). Data are for descent to Lone Star on 12 October, 00:37 local time.
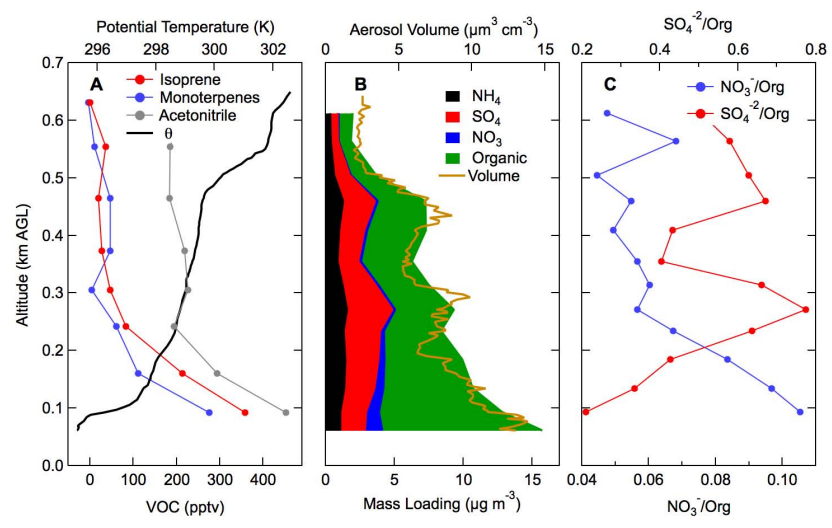

Fig. 13. Vertical profile from the descent to Lone Star airfield on 12 October. (A) Mixing ratio of isoprene, monoterpenes and acetonitrile (bottom axis) and potential temperature profile (top axis). (B) Mass loading of ammonium, sulfate, nitrate and organic from the AMS (bottom axis), and total aerosol volume (top axis). (C) Ratio of nitrate and sulfate to organic mass (bottom and top axes, respectively).

large fraction of the radical flux $\left(P\left(\mathrm{NO}_{3}\right)=1-2 \mathrm{ppbv} \mathrm{h}^{-1}\right)$ was consumed by BVOC oxidation. Peaks in all components of aerosol mass in panel $\mathrm{C}$ occurred at low altitude, but were substantially wider than the peaks in $P\left(\mathrm{NO}_{3}\right)$ or BVOC from the first two panels. The wider peaks in the time series represent a greater depth on each profile, consistent with an enhancement in all aerosol types associated with the residual layer. Narrower peaks in organic and nitrate, but not sulfate or ammonium, occurred at the bottom of each profile, coincident with the low altitude peaks in $P\left(\mathrm{NO}_{3}\right)$ and BVOC.

The first vertical profile in this series was the descent to Lone Star (Fig. 12). Mixing ratios of $\mathrm{NO}_{3}$ and $\mathrm{N}_{2} \mathrm{O}_{5}$ (panel A) exhibited distinct, narrow plume structure likely 
associated with transport of $\mathrm{NO}_{\mathrm{x}}$ from different emission sources within a stable boundary layer (Brown et al., 2012). Mixing ratios of both compounds dropped off markedly below the sharp change in potential temperature near $100 \mathrm{~m}$ that marked the top of the NBL on this profile. The $\mathrm{NO}_{\mathrm{x}}$ pollution was concentrated below this level (panel B), but strongly anti-correlated with $\mathrm{O}_{3}$, resulting in a maximum $P\left(\mathrm{NO}_{3}\right)$ of $2 \mathrm{ppbvh}^{-1}$ just above the NBL and $0.5-1 \mathrm{ppbvh}^{-1}$ within the NBL (panel C). Lone Star airfield is adjacent to the city of Conroe, TX, which was immediately upwind of the airfield on this profile. The $\mathrm{NO}_{\mathrm{x}}$ profile, which shows peak mixing ratios of 45-55 ppbv $\mathrm{NO}_{2}$ and nearly complete titration of $\mathrm{O}_{3}$ below the NBL, may reflect an urban background from Houston, the contribution of local urban emissions from Conroe, or a local influence due to biomass burning.

The VOC and aerosol data for the same profile (Fig. 13) show clear and relatively large enhancements in both isoprene and monoterpenes just above and within the NBL, consistent with the location of this profile in an area of large biogenic emission. It also showed an enhancement in acetonitrile, a marker for the influence of biomass burning. Acetonitrile enhancements also occurred at other locations on this flight within the residual layer, although the residual layer did not have enhanced acetonitrile on this particular profile. Aerosol was also enhanced at low altitude, and the vertical structure of this enhancement is clearer in this vertical view than in the time series shown in Fig. 11. The potential temperature indicates a stable layer at $0.5-0.6 \mathrm{~km}$ (see above), beneath which were increases in all aerosol components. The presence of sulfate within this residual layer most likely indicates the influence of the previous day's photochemistry, since $\mathrm{SO}_{2}$ oxidation is likely to have been negligible in the dark under cloud free conditions such as those sampled here. Since the profile occurred more than $5 \mathrm{~h}$ after sunset, the upper layers were also likely influenced by nighttime chemistry.

As in the preceding examples, the largest organic aerosol enhancement occurred at the lowest altitude, within the NBL. The vertical dependence in the ratios of sulfate and nitrate to organic in Fig. 13c are similar to the preceding examples, with increasing nitrate and organic, but not sulfate or ammonium, with decreasing altitude. As in the other profiles, the increase in aerosol ammonium was coincident with higher $\mathrm{NH}_{3}$ in the residual layer and NBL. Similar to the descent at Hobby on 8 October, the average measured to calculated ammonium was somewhat high $(1.6 \pm 1.0)$, the decrease in gas phase $\mathrm{HNO}_{3}$ was much larger than the increase in aerosol nitrate, and the ratio of $\mathrm{m} / z 30$ to $\mathrm{m} / \mathrm{z} 46$ was $4.6 \pm 0.6$, much larger than for pure ammonium nitrate particles. Furthermore, the lack of an ammonium enhancement on this profile suggests that the observed nitrate increase is dominated by organics in this case.

Figure 14 shows the comparison of the organic enhancement on this profile to the estimated contribution from primary emissions. Analysis of the OA spectra suggest that approximately $50 \%$ of the low altitude enhancement in or-
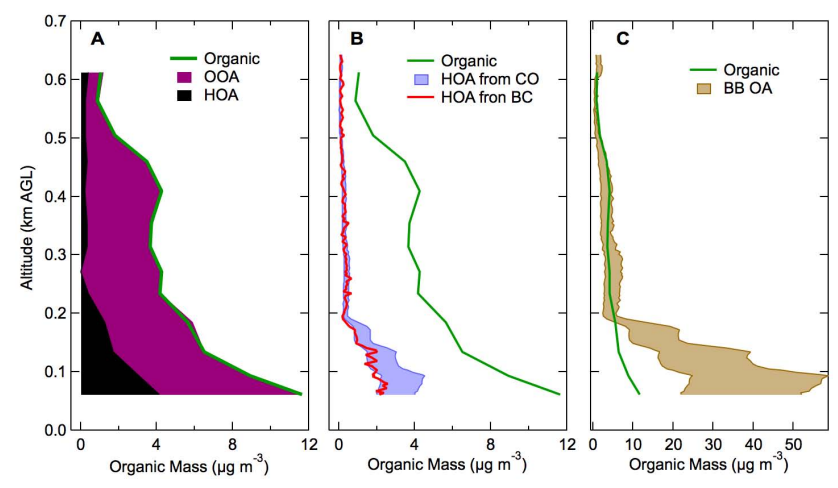

Fig. 14. Vertical profile from descent to Lone Star airfield on 12 October showing (A) organic mass loading in comparison to OOA and HOA derived from the AMS the AMS; (B) organic mass loading compared to HOA derived from a parameterization against $\mathrm{CO}$ and black carbon (BC) for urban emissions (see text). (C) Organic mass loading compared to biomass burning emissions derived from $\mathrm{CO}$ if all of the $\mathrm{CO}$ enhancement above background were attributable to biomass burning (see text).

ganic aerosol was due to primary emissions, and $50 \%$ to a secondary source. Primary aerosol mass loadings estimated from $\mathrm{BC}$ and $\mathrm{CO}$ give a range of $25-40 \%$ of the observed $\mathrm{OA}$ enhancement if the organic aerosol is from an urban source. However, the concurrent enhancement in acetonitrile (Fig. 13) on this profile indicates the influence of biomass burning could have been large enough to explain the entire OA enhancement. Biomass burning OA emissions relative to $\mathrm{CO}$ are $55-130 \mu \mathrm{m} \mathrm{m}^{-3}$ per ppmv $\mathrm{CO}$ (de Gouw and Jimenez, 2009).

Figure $14 \mathrm{c}$ shows the predicted OA enhancement if all of the $\mathrm{CO}$ in excess of a $100 \mathrm{ppbv}$ background were attributable to biomass burning. This biomass burning OA is well in excess of observations, indicating that the $\mathrm{CO}$ was likely from multiple sources (not all biomass burning $\mathrm{CO}$ ). The overprediction of observed OA by the parameterization against $\mathrm{CO}$ does indicate that a large fraction of the observed $\mathrm{OA}$ could have been from local fires. The influence of biomass burning aerosol on the partitioning between HOA and OOA from the AMS is not clear, although a levoglucosan related fragment $(m / z=60$, Aiken et al., 2007) did not show large enhancements, making the influence of biomass burning on either component difficult to assess. Thus, the vertical variation of $\mathrm{NO}_{\mathrm{x}}$ and organic aerosol in Fig. 14 may have been due to local urban sources, secondary nighttime sources, biomass burning, or some combination of the three.

Figure 15 shows the correlation between organic mass and $\mathrm{CO}$ in both the residual layer and the NBL for low approaches to Lone Star and Hobby on 12 October. In contrast to the 11 October data, organic mass in the residual layer was well correlated with the $\mathrm{CO}$ tracer, with $\Delta \mathrm{OA} / \triangle \mathrm{CO}$ slopes of $64 \pm 5$ and $79 \pm 6 \mu \mathrm{g} \mathrm{m}^{-3} / \mathrm{ppmv} \mathrm{CO}$, similar to or even somewhat larger than those previously determined 

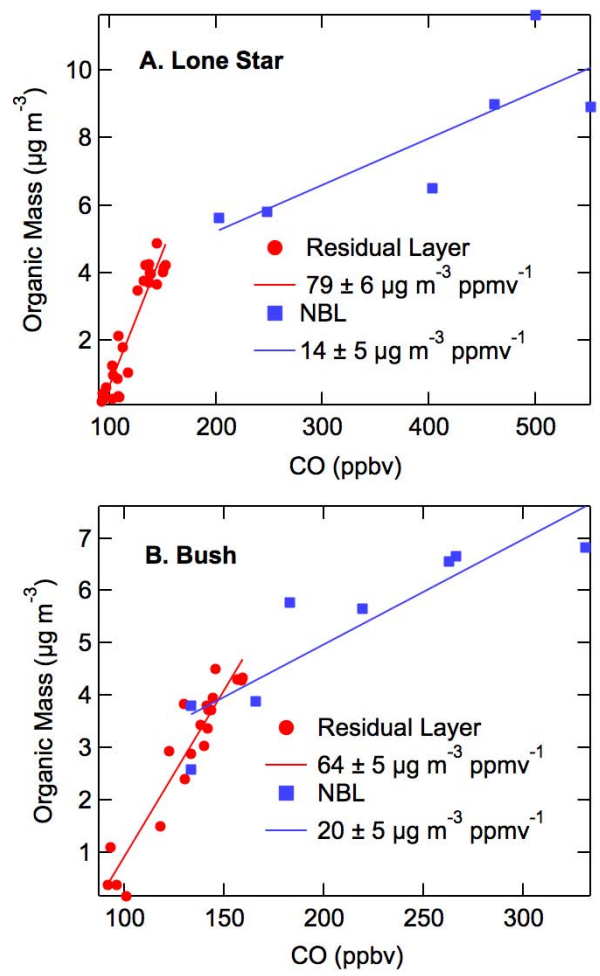

Fig. 15. Plot of organic aerosol mass $\left(\mu \mathrm{g} \mathrm{m}^{-3}\right)$ from the AMS against carbon monoxide (CO) in ppbv for the profiles at (A) Lone Star and (B) Bush airfield on 12 October. Red and blue data points are for the residual and nocturnal boundary layers, respectively. Slopes of linear fits to each data set are shown in the caption.

for photochemically produced aerosol from urban Houston (Bahreini et al., 2009). These slopes may reflect the sum of both photochemical and nighttime OA production if the latter were significant within the residual layer. The lower $\triangle \mathrm{OA} / \triangle \mathrm{CO}$ slopes in the NBL are greater than the range predicted for primary urban emissions, but may have been influenced by biomass burning and secondary processes.

\subsection{Summary of nighttime vertical profile characteristics}

Although the individual profiles for each of the cases described above exhibited substantial variability, they also share a set of common characteristics that indicates both active nighttime chemistry that, in some cases, leads to both rapid BVOC oxidation and secondary aerosol production. First, nitrate radical production rates, $P\left(\mathrm{NO}_{3}\right)=$ $k_{\mathrm{NO}_{2}+\mathrm{O}_{3}}\left[\mathrm{O}_{3}\right]\left[\mathrm{NO}_{2}\right]$, were consistently large at low altitude (0.5-2.7 $\left.\mathrm{ppbv} \mathrm{h}^{-1}\right)$ in urban influenced air and were comparable to or greater than primary $\mathrm{OH}$ radical production rates during daytime. Second, $\mathrm{NO}_{2}$ mixing ratios at low altitude were tightly anticorrelated with $\mathrm{O}_{3}$, indicating that the chemical transformations of these species were dominated by nighttime chemistry rather than photochem- istry. Third, many profiles exhibited distinct increases in BVOC mixing ratios at low altitude, consistent with nighttime BVOC emissions into a shallow boundary layer (also see Sect. 5). BVOC enhancements were apparent in measurements from both the PTRMS (high time resolution) and the canister samples (low time resolution, better speciation) instruments. Fourth, the inverse lifetime of $\mathrm{NO}_{3}$, $\tau\left(\mathrm{NO}_{3}\right)^{-1}=P\left(\mathrm{NO}_{3}\right) / \mathrm{NO}_{3}$, was well correlated with and comparable to the first-order $\mathrm{NO}_{3}$ loss rate coefficients for $\mathrm{NO}_{3}, k\left(\mathrm{NO}_{3}\right)=\Sigma_{i} k\left(\mathrm{NO}_{3}+\mathrm{BVOC}\right)_{i} *[\mathrm{BVOC}]_{i}$, determined from PTRMS measurements of BVOC concentrations, implying a large fraction of $\mathrm{NO}_{3}$ radical production consumed by $\mathrm{NO}_{3}-\mathrm{BVOC}$ reactions. Fifth, organic and nitrate aerosol mass were more consistently enhanced at low altitude than were sulfate or ammonium aerosol mass, with several instances of substantial organic enhancements $\left(>4 \mu \mathrm{g} \mathrm{m}^{-3}\right)$. Organic enhancement is consistent with a secondary organic aerosol source from $\mathrm{NO}_{3}+\mathrm{BVOC}$ reactions, although in vertical profiles from the 12 October flight, these effects cannot be separated from organic aerosol emissions from biomass burning. Nitrate enhancement is consistent with a source from either organic nitrate aerosol formation or inorganic nitrate arising from hydrolysis of $\mathrm{N}_{2} \mathrm{O}_{5}$ and partitioning of $\mathrm{HNO}_{3}$ to ammonium nitrate. Sixth, for nonbiomass burning influenced air, a substantial fraction of organic aerosol enhancements were inferred to arise from secondary sources based on a multivariate regression analysis of the AMS. Finally, organic aerosol enhancements in the NBL were correlated with $\mathrm{CO}$, with slopes of $\triangle \mathrm{OA} / \triangle \mathrm{CO}$ comparable to or slightly smaller than those inferred from photochemical organic aerosol generation in urban plumes. Some slopes were also likely influenced by biomass burning sources.

\section{Average aerosol profiles}

Differences in the average vertical structure of aerosol composition illustrate the differences in sources for each and provide further evidence for a nighttime source of organic and nitrate aerosol. Figure 16 shows the average, normalized mass loading of organic, sulfate, nitrate and ammonium for the ten late night profiles on 11 and 12 October (five from each flight, two low approaches and one landing). These profiles all occurred more than five hours after sunset and spanned the two different transport regimes (north to south and the reverse) described above. The averages of profiles from 8 October and 29 September, which all occurred earlier in the evening, show the same dependences of organic, sulfate and nitrate with height, but with smaller relative variation as a function of altitude. Data are averaged to $50 \mathrm{~m}$ vertical resolution and normalized to the value above the boundary layer (400-1000 m on 11 October, 700-1000 m on 12 October). Normalized loadings illustrate the relative enhancements with decreasing height through the boundary 
layer structure. Panels A and C show the comparison of organic to sulfate, which are similar in scale, while panels B and $\mathrm{D}$ also include nitrate and ammonium. On 11 October during southward transport across the urban area within a relatively deep NBL, there was little enhancement in sulfate, derived mainly from photochemistry, within the NBL. The small sulfate enhancement below $400 \mathrm{~m}$ in Fig. 16a was due entirely to excess sulfate on approach to Ellington Field, immediately downwind of the Houston Ship Channel and presumably from a primary local source. Organic enhancements across all five profiles were similar in shape and magnitude, indicating an area-wide source. Relative enhancements in nitrate and ammonium are shown in Fig. 16b on a different scale. Although there was much less mass in these components, their relative enhancements were larger because of the small mass aloft. The shapes of these two components were similar, and distinct from that of sulfate, indicating that at least some fraction of the aerosol nitrate was associated with ammonium and therefore likely inorganic (see Sect. 3.2).

The boundary layer structure on 12 October exhibited a residual layer extending to approximately $700 \mathrm{~m}$ and with a shallow NBL at 150-200 m (Sect. 3.3). Sulfate enhancements (Fig. 16c) were large within the residual layer, but decreased in the NBL, while organic was enhanced within the residual layer and then further enhanced within the NBL. The large relative organic enhancement in the NBL for this flight is more difficult to interpret due to the likely influence of biomass burning aerosol. A nighttime secondary organic aerosol source in the NBL is plausible, but impossible to separate from the influence of biomass burning. The pattern of nitrate and ammonium in Fig. 16d is different than 11 October (panel B). Here, the ammonium enhancements follow those of sulfate, increasing in the residual layer but decreasing in the NBL, while the nitrate follows the organic, increasing successively in both layers. The association of nitrate with organic, and the lack of association with ammonium, is suggestive of organic nitrate aerosol (again, relative nitrate enhancements are large due to the small nitrate mass loading above $700 \mathrm{~m}$ ). The association of these components even in the residual layer suggests that the observed nitrate may be organic, rather than inorganic, throughout the layer structure. This observation implies that reactive nitrogen may have played a role in SOA formation process in all observed layers.

\section{VOC oxidation rates}

Table 2 summarizes the biogenic VOC and oxidant data within the NBL for the airfield approaches and landing on 11 and 12 October, shown in Fig. 5 and Fig. 10, respectively. The table gives mixing ratios measured by both PTRMS and the canister samples (WAS). As noted above, the PTRMS is an upper limit if it is subject to interference at the masses used to measure isoprene or monoterpenes, whereas the WAS
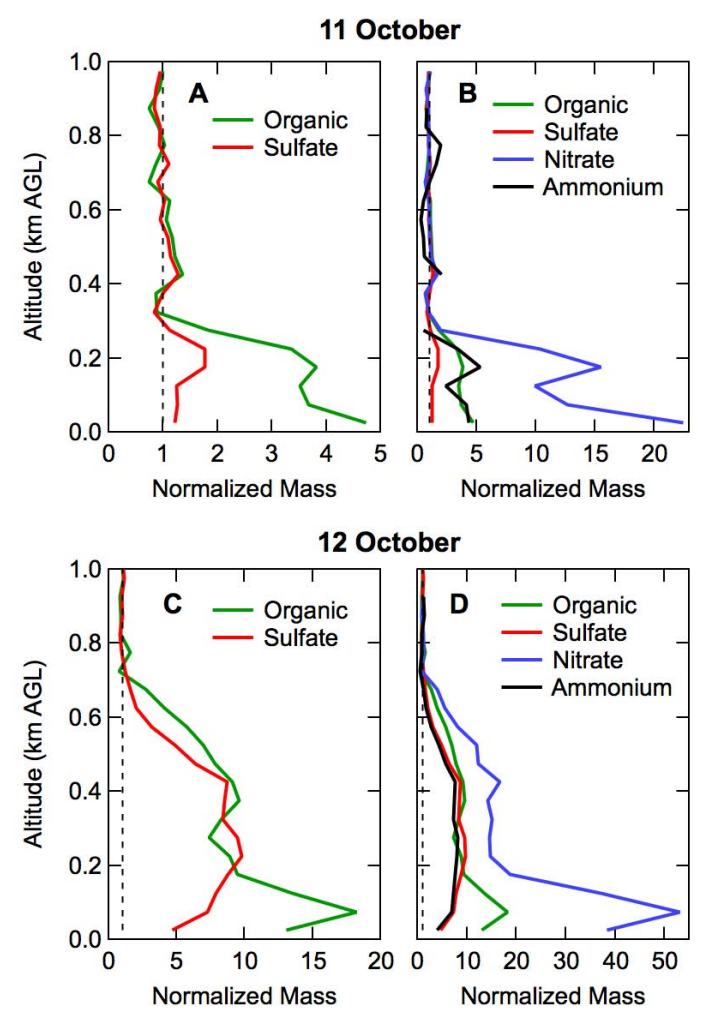

Fig. 16. Normalized mass loading of aerosol organic, sulfate, nitrate and ammonium from the average of 5 vertical profiles between midnight and 01:00 LT on 11 October $(\mathbf{A}, \mathbf{B})$ and 12 October $(\mathbf{C}$, D). Panels (B) and (D) show the same data for organics and sulfate as do (A) and (C), respectively, but on a scale that is also appropriate for nitrate and ammonium. Mass loadings are averaged into $50 \mathrm{~m}$ bins and normalized to the value above the boundary layer (400-1000 m on 11 October, $700-1000 \mathrm{~m}$ on 12 October) to show relative enhancements as a function of decreasing height for each flight.

is a lower limit because not all speciated monoterpenes were reported. Where data are absent or below detection limit (30 pptv for PTRMS), there are no entries in the table. The table also gives first-order loss rate coefficients for monoterpenes (using the rate coefficient for $\alpha$-pinene) and for isoprene with respect to each oxidant, in units of $\mathrm{h}^{-1}$. These loss rate coefficients were substantially larger for $\mathrm{NO}_{3}$ than for $\mathrm{O}_{3}$, even though the $\mathrm{NO}_{3}$ mixing ratios were in some cases quite small. The last columns of the table also give net VOC loss rates associated with both the larger PTRMS and the smaller WAS measurements. Total $\left(\mathrm{NO}_{3}+\mathrm{O}_{3}\right)$ loss rate coefficients for monoterpenes range from 0.3 to $>3 \mathrm{~h}^{-1}$, such that net oxidation rates for these species must be balanced by nighttime emission (i.e., an approximate steady state in the VOC) for these compounds to be present 5-6h after sunset. The derived monoterpene oxidation rates were larger on 12 October than on 11 October; this observation is consistent with the shallower boundary layer on 12 October, which 
would lead to larger mixing ratios for the same surface level emission rates and a more rapid apparent oxidation rate. Total loss rate coefficients for isoprene were slower, 0.05 to $>0.4 \mathrm{~h}^{-1}$. The oxidation of isoprene, whose emissions are temperature and light dependent, was not rapid enough to require a steady state with an emission source; the observations are consistent with either nighttime isoprene decay, or with a much weaker nighttime emission source.

Oxidation rates inferred here may be compared to biogenic VOC emission rates. For example, the daytime isoprene emission source in the Houston urban area during this study were on the order of $100 \mathrm{~mol} \mathrm{k} \mathrm{km}^{-2} \mathrm{~h}^{-1}$ (Warneke et al., 2010), which if mixed into a shallow boundary layer $(100 \mathrm{~m})$ would be equivalent to $4.8 \mathrm{ppbv}$ isoprene $\mathrm{h}^{-1}$. The inferred isoprene oxidation rates of $0.01-0.04 \mathrm{ppbv} \mathrm{h}^{-1}$ from the PTR measurements were more than 2 orders of magnitude slower, such that the nighttime vegetative isoprene emission source implied by this analysis would be less than $1 \%$ of daytime, sunlight driven emissions. The same is not true for monoterpenes, which have nighttime oxidation rates of 0.1-1.2 $\mathrm{ppbv} \mathrm{h}^{-1}$. Monoterpene emission rates from BEIS3 inventory near Bush, Hooks and Lone Star airfields in the range $20-30 \mathrm{~mol} \mathrm{C} \mathrm{km}^{-2} \mathrm{~h}^{-1}$ (see Fig. 1) would be equivalent to $0.5-0.75 \mathrm{ppbv}^{-1}$ in a $100 \mathrm{~m}$ boundary layer and $0.13-0.19 \mathrm{ppbv} \mathrm{h}^{-1}$ in a $400 \mathrm{~m}$ boundary layer. These emission rates are approximately comparable to the inferred oxidation rates of $1 \mathrm{ppbvh}^{-1}$ at Bush on 12 October $(100 \mathrm{~m}$ $\mathrm{NBL}$ ) and $0.2 \mathrm{ppbv} \mathrm{h}^{-1}$ on 11 October (400 m NBL).

\section{Box model simulations}

A box model simulation that represents chemistry during transport under a fixed, shallow nocturnal boundary layer provides a comparison to the observed enhancements of VOCs, inferred oxidation rates and aerosol production within the NBL. The purpose of the model is to determine if nighttime monoterpene emission and oxidation, together with laboratory SOA yields for $\mathrm{NO}_{3}$ and $\mathrm{O}_{3}$ reactions, are consistent with the observed low altitude, nighttime organic aerosol enhancements. The model simulation illustrates the relative contributions of $\mathrm{NO}_{3}$ and $\mathrm{O}_{3}$ to BVOC oxidation and $\mathrm{SOA}$ formation. It is meant to provide a test of the physical plausibility of the interpretation presented in the preceding sections, rather than a definitive reproduction of the nighttime chemistry.

The model assumes a uniform area emission of monoterpenes and a fixed mixing ratio of isoprene present at sunset, the start time for the model, with no nighttime isoprene emissions. For simplicity, monoterpene emissions are divided equally between $\alpha$ - and $\beta$-pinene, with no emission of other monoterpenes. Table 3 summarizes the kinetic data for the reactions and emissions included. Reactions with $\mathrm{NO}_{3}$ consume the monoterpenes and lead to either organic nitrate production or recycling of $\mathrm{NO}_{2}$. For example, Hallquist et al. (1999) report $20 \%$ and $70 \%$ organic nitrate production from $\alpha$ and $\beta$-pinene, respectively. The partial recycling of $\mathrm{NO}_{2}$ in these reactions prevents $P\left(\mathrm{NO}_{3}\right)$ from decreasing as rapidly as it would if the reactive nitrogen were converted exclusively to organic nitrates. The simulation includes heterogeneous hydrolysis of $\mathrm{N}_{2} \mathrm{O}_{5}$ with a first order loss rate coefficient, $k\left(\mathrm{~N}_{2} \mathrm{O}_{5}\right)=2 \times 10^{-4} \mathrm{~s}^{-1}$, or a lifetime of approximately $1.4 \mathrm{~h}$. This rate coefficient is equivalent to an uptake coefficient of $\gamma\left(\mathrm{N}_{2} \mathrm{O}_{5}\right)=5 \times 10^{-3}$ (Brown et al., 2009b) and an aerosol surface area of $750 \mu \mathrm{m}^{2} \mathrm{~cm}^{-3}$, the average, ambient aerosol surface area on the Hooks profile on October 8, described in Sect. 3.1. Due to their large emission rates, monoterpene reactions dominate losses of $\mathrm{NO}_{3}$ and $\mathrm{N}_{2} \mathrm{O}_{5}$ in the simulations. The model estimates the contribution of peroxy radical $\left(\mathrm{RO}_{2}\right)$ reactions with $\mathrm{NO}_{3}$ by directly producing $\mathrm{RO}_{2}$ in the $\mathrm{NO}_{3}+\mathrm{BVOC}$ reaction, with subsequent reactions of the peroxy radicals with either $\mathrm{RO}_{2}$ or $\mathrm{NO}_{3}$. Reaction of $\mathrm{NO}_{3}$ with peroxy radicals recycles $\mathrm{NO}_{2}$. The model calculates a range of SOA based on the total monoterpene reacted with either $\mathrm{NO}_{3}$ or $\mathrm{O}_{3}$ and a range of potential yields for each reaction. The model does not include SOA from isoprene oxidation. The upper limit for the $\mathrm{SOA}$ yield from $\mathrm{NO}_{3}$ reaction with monoterpenes is $14 \%$, based on the parameterization of Griffin et al. (1999) for $\beta$-pinene at an aerosol mass of $10 \mu \mathrm{g} \mathrm{m}^{-3}$. This treatment is similar to that used in other atmospheric models (Hoyle et al., 2007; Pye et al., 2010). The lower limit for SOA yield from this reaction is $3 \%$, based on the yield for $\beta$-pinene at $5 \mu \mathrm{g} \mathrm{m}^{-3}$ and no contribution from $\alpha$-pinene. The simulated SOA yield for $\mathrm{O}_{3}$ range from $5-10 \%$ based on a lower limit from equal contributions from $\alpha$ - and $\beta$-pinene at $5 \mu \mathrm{g} \mathrm{m}^{-3}$ and an upper limit from $\alpha$ pinene alone at $10 \mu \mathrm{g} \mathrm{m}^{-3}$ (Griffin et al., 1999). The differential equations corresponding to this set of reactions were numerically integrated using an adaptive step size (RungeKutta) method.

Figure 17 shows a simulation for the case of a large $\mathrm{NO}_{3}$ production rate and a large biogenic VOC emission rate, similar to what might occur during advection of an air mass northward out of Houston. The $\mathrm{NO}_{2}$ and $\mathrm{O}_{3}$ mixing ratios for this simulation are similar to those in the NBL at Hooks on 8 October (Fig. 3, $\mathrm{NO}_{2}=18 \mathrm{ppbv}, \mathrm{O}_{3}=45 \mathrm{ppbv}$ ), with $P\left(\mathrm{NO}_{3}\right)$ in excess of $2 \mathrm{ppbv} \mathrm{h}^{-1}$ initially. The monoterpene emission rate in this simulation is $1 \mathrm{ppbv} \mathrm{h}^{-1}$, equivalent to $70 \mathrm{~mol} \mathrm{C} \mathrm{km}^{-2} \mathrm{~h}^{-1}$ emitted into a $150 \mathrm{~m}$ deep NBL, and divided equally between $\alpha$ and $\beta$-pinene. This emission rate is consistent with the BEIS3 inventory at a temperature of $30^{\circ} \mathrm{C}$. The nighttime temperature at the lowest altitude on the Hooks profiles was $23.7^{\circ} \mathrm{C}$, corresponding to a temperature correction factor of $57 \%$ of the emission potential, or $40 \mathrm{~mol} \mathrm{k} \mathrm{km}^{-2} \mathrm{~h}^{-1}$. The use of the larger emission in the model thus represents warmer conditions than measured on this October flight, and is intended to simulate a maximum aerosol formation potential. Initial isoprene is $0.5 \mathrm{ppbv}$ to represent that remaining from the daytime emission. Figure $17 \mathrm{c}$ compares the simulated $\tau\left(\mathrm{NO}_{3}\right)^{-1}$ and $k\left(\mathrm{NO}_{3}\right)$, as 
Table 3. Chemical mechanism for nighttime box model.

\begin{tabular}{|c|c|c|}
\hline Reaction & Rate Coefficient* & Reference/Notes \\
\hline $\mathrm{NO}+\mathrm{O}_{3} \rightarrow \mathrm{NO}_{2}+\mathrm{O}_{2}$ & $1.4 \times 10^{-12} \exp (-1310 / T)$ & Atkinson et al. (2004) \\
\hline $\mathrm{NO}_{2}+\mathrm{O}_{3} \rightarrow \mathrm{NO}_{3}+\mathrm{O}_{2}$ & $1.4 \times 10^{-13} \exp (-2470 / T)$ & Atkinson et al. (2004) \\
\hline $\mathrm{NO}_{2}+\mathrm{NO}_{3}+\mathrm{M} \rightarrow \mathrm{N}_{2} \mathrm{O}_{5}+\mathrm{M}$ & $1.9 \times 10^{-12}(T / 300)^{0.2}$ & Atkinson et al. (2004) \\
\hline $\mathrm{N}_{2} \mathrm{O}_{5}+\mathrm{M} \rightarrow \mathrm{NO}_{3}+\mathrm{NO}_{2}+\mathrm{M}$ & $1.3 \times 10^{-3}(T / 300)^{-3.5} \exp (-11000 / T)[\mathrm{M}\}$ & Atkinson et al. (2004) \\
\hline $\mathrm{NO}_{3}+\mathrm{NO} \rightarrow 2 \mathrm{NO}_{2}$ & $1.8 \times 10^{-11} \exp (110 / T)$ & Atkinson et al. (2004) \\
\hline $\mathrm{N}_{2} \mathrm{O}_{5}+\mathrm{H}_{2} \mathrm{O}$ (het) $\rightarrow 2 \mathrm{HNO}_{3}$ & $k=1 / 4 \gamma c S_{\mathrm{A}}=2 \times 10^{-4} \mathrm{~s}^{-1}$ & $\begin{array}{l}\gamma=0.005 ; S_{\mathrm{A}}=750 \mu \mathrm{m}^{2} \mathrm{~cm}^{-3} \\
c=\text { mean speed of } \mathrm{N}_{2} \mathrm{O}_{5}\end{array}$ \\
\hline $\mathrm{NO}_{3}+\alpha$-pinene $\rightarrow \mathrm{RO}_{2}+\Phi_{1} \mathrm{NO}_{2}+\Phi_{2} \mathrm{SOA}$ & $\begin{array}{l}k=1.2 \times 10^{-12} \exp (490 / T) \Phi_{1}=80 \% \\
\Phi_{2}=\text { SOA yield from }(\text { Griffin et al., } 1999), \text { see text }\end{array}$ & $\begin{array}{l}\text { Griffin et al. (1999); Hallquist } \\
\text { et al. (1999); Atkinson et al. (2004) }\end{array}$ \\
\hline $\mathrm{NO}_{3}+\beta$-pinene $\rightarrow \mathrm{RO}_{2}+\Phi_{3} \mathrm{NO}_{2}+\Phi_{4} \mathrm{SOA}$ & $\begin{array}{l}k=2.5 \times 10^{-12} ; \Phi_{3}=30 \% \\
\Phi_{4}=\text { SOA yield from Griffin et al. (1999), see text }\end{array}$ & $\begin{array}{l}\text { Griffin et al. (1999); Hallquist } \\
\text { et al. (1999); Atkinson and Arey (2003) }\end{array}$ \\
\hline $\mathrm{NO}_{3}+$ Isoprene $\rightarrow \mathrm{RO}_{2}+\Phi_{5} \mathrm{NO}_{2}$ & $k=3.15 \times 10^{-12} \exp (-450 / T) \Phi_{5}=30 \%$ & Atkinson et al. (2004); Rollins et al. (2009) \\
\hline $\mathrm{NO}_{3}+\mathrm{RO}_{2} \rightarrow \mathrm{NO}_{2}+$ Products & $2 \times 10^{-12} \mathrm{~cm}^{3} \mathrm{~s}^{-1}$ & Vaughan et al. (2006) \\
\hline $\mathrm{RO}_{2}+\mathrm{RO}_{2} \rightarrow$ Products & $2 \times 10^{-12} \mathrm{~cm}^{3} \mathrm{~s}^{-1}$ & Jenkin and Boyd (1998) \\
\hline $\mathrm{O}_{3}+\alpha$-pinene $\rightarrow \mathrm{RO}_{2}+\Phi_{6} \mathrm{SOA}$ & $6.3 \times 10^{-16} \exp (-580 / T)$ & Griffin et al. (1999); Atkinson et al. (2004) \\
\hline $\mathrm{O}_{3}+\beta$-pinene $\rightarrow \mathrm{RO}_{2}+\Phi_{7} \mathrm{SOA}$ & $\begin{array}{l}1.2 \times 10^{-15} \exp (-1300 / T) \\
\Phi_{7}=\text { SOA yield from Griffin et al. (1999), see text }\end{array}$ & $\begin{array}{l}\text { Griffin et al. (1999); } \\
\text { Atkinson and Arey (2003) }\end{array}$ \\
\hline $\mathrm{O}_{3}+$ Isoprene $\rightarrow \mathrm{RO}_{2}$ & $1.03 \times 10^{-14} \exp (-1995 / T)$ & Atkinson et al. (2004) \\
\hline Emission Source $\rightarrow \alpha$-pinene & $1 / 2\left(15-70 \mathrm{~mol} \mathrm{C} \mathrm{km}^{2} \mathrm{~h}^{-1}\right)$ & BEIS3, see text \\
\hline Emission Source $\rightarrow \beta$-pinene & $1 / 2\left(15-70 \mathrm{~mol} \mathrm{C} \mathrm{km}^{2} \mathrm{~h}^{-1}\right)$ & BEIS3, see text \\
\hline
\end{tabular}

* Temperature dependent $\left(T=\right.$ absolute temperature) rate coefficients in units of $\mathrm{cm}^{3}$ molecule ${ }^{-1} \mathrm{~s}^{-1}$ unless otherwise specified.

defined above, where the latter is calculated from $\mathrm{NO}_{3}$ reactions with simulated isoprene, and $\alpha$ and $\beta$-pinene. As in the observations, the two quantities are similar in magnitude with the main difference arising from the estimated contribution of peroxy radical reactions to consumption of $\mathrm{NO}_{3}$. In the simulation, isoprene decays rapidly, but not as rapidly as it would if it were the only VOC reacting with $\mathrm{NO}_{3}$. Monoterpenes enter a steady state with $\mathrm{NO}_{3}$ at mixing ratios near $100 \mathrm{pptv}$ for much of the simulation, increasing at later times as the $\mathrm{NO}_{3}$ production rate declines.

Figure $17 \mathrm{~d}$ shows the range of potential SOA from $\mathrm{NO}_{3}$ and $\mathrm{O}_{3}$ oxidation of the monoterpenes. There is little contribution to $\mathrm{SOA}$ from $\mathrm{O}_{3}$ because little of the emitted monoterpenes react with $\mathrm{O}_{3}$. In a simulation with $\mathrm{NO}_{2}$ removed (not shown), the estimated SOA production from $\mathrm{O}_{3}$ ranges from $1-3 \mu \mathrm{g} \mathrm{m}^{-3}$, approximately $2-3$ times smaller than that produced with the large $\mathrm{NO}_{3}$ production rate included in the simulation. Reduced SOA in the $\mathrm{O}_{3}$ only simulation is due to both slower oxidation rates (smaller total mass of monoterpene reacted) and somewhat smaller $\mathrm{OA}$ yields from $\mathrm{O}_{3}$ reactions. The simulation demonstrates that $\mathrm{NO}_{3}$ reactions have the potential to produce organic aerosol mass loadings of several $\mu \mathrm{g} \mathrm{m}^{-3}$ overnight, which is consistent with the range of observed enhancements within the NBL during vertical profiles.

Figure 18 shows a simulation with reduced biogenic VOC emission rates to represent BVOC oxidation within the urban area. Here, monoterpene emissions are set to $0.2 \mathrm{ppbv} \mathrm{h}^{-1}$, equivalent to $15 \mathrm{~mol} \mathrm{C} \mathrm{km}^{2} \mathrm{~h}^{-1}$ into a $150 \mathrm{~m}$ boundary layer (see Fig. 1). The nitrate radical production rate in this simulation is also smaller, $1 \mathrm{ppbv} \mathrm{h}^{-1}$, at sunset, similar to condi- tions of the $10-11$ October flight. No additional $\mathrm{NO}_{\mathrm{x}}$ emissions have been assumed during overnight transport over the urban area. Other simulation parameters are the same as the preceding example. This simulation produces much less SOA due to the lower emission rates of the monoterpenes. Nevertheless, the $\mathrm{NO}_{3}$ loss rate coefficient to biogenic VOCs $\left(k\left(\mathrm{NO}_{3}\right)\right)$ tracks the $\mathrm{NO}_{3}$ reactivity $\left(\tau\left(\mathrm{NO}_{3}\right)^{-1}\right)$ in time and is the largest $(\sim 50 \%)$ contribution to it. Predicted mixing ratios of monoterpenes and isoprene are lower than those measured from the PTRMS within the NBL over the urban area, with a maximum mixing ratio in the simulation of $34 \mathrm{pptv}$ and an average of $16 \mathrm{pptv}$. As in the preceding model calculation, most of the produced SOA comes from $\mathrm{NO}_{3}$-monoterpene reactions (no isoprene $\mathrm{SOA}$ in the model) rather than $\mathrm{O}_{3}$ reactions. Total SOA ranges from 0.5$2 \mu \mathrm{g} \mathrm{m}^{-3}$ in $10 \mathrm{~h}$ and $0.2-1 \mu \mathrm{g} \mathrm{m}^{-3}$ in $5 \mathrm{~h}$. This SOA production is somewhat smaller than would be inferred from the secondary source on profiles taken 5-6h after dark on 10 October. The smaller values suggest the potential for slightly larger monoterpene emissions over the urban area, or that some of the observed SOA formed upwind of the urban area in more biogenic rich regions. The comparison of the two simulations gives an estimate of the range of modeled nighttime biogenic SOA under different assumptions.

\section{Conclusions}

Nighttime vertical profiles from the NOAA P-3 aircraft from low approaches to airfields in the Houston, Texas region have provided a unique look at the structure and chemical 

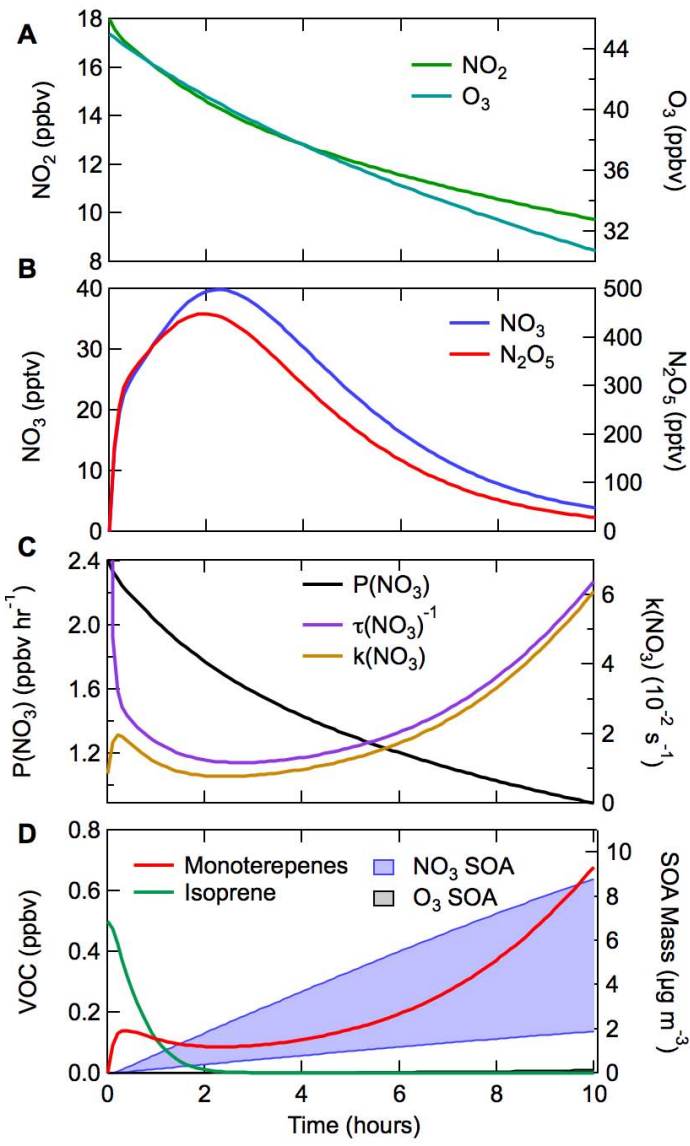

Fig. 17. Model simulation of a large $\mathrm{NO}_{3}$ source and a large biogenic VOC emission source, intended to represent an urban air mass transported to a forested region. (A) $\mathrm{NO}_{2}, \mathrm{O}_{3}$; (B) $\mathrm{NO}_{3}, \mathrm{~N}_{2} \mathrm{O}_{5}$; (C) nitrate radical production rate, $P\left(\mathrm{NO}_{3}\right)$ (left axis), and inverse steady-state lifetime, $\tau\left(\mathrm{NO}_{3}\right)^{-1}$, and first-order loss rate coefficient to biogenic VOCs, $k\left(\mathrm{NO}_{3}\right)$, plotted together on the right axis. (D) Summed monoterpenes ( $\alpha$ - and $\beta$-pinene) and isoprene (left axis), and SOA mass from $\mathrm{NO}_{3}$ and $\mathrm{O}_{3}$ oxidation of these VOCs (right axis). The blue shaded range indicates high and low SOA yields (see text) for monoterpene oxidation. Note that SOA from $\mathrm{O}_{3}$ oxidation is small and barely visible on the scale of $\mathrm{SOA}$ from $\mathrm{NO}_{3}$ oxidation in this simulation.

composition of the NBL and residual layer in this polluted urban area. The observations show that (1) nitrate radical production rates were consistently large at low altitude within the NBL; (2) BVOCs, including monoterpenes and isoprene, were also concentrated within the NBL, with rapid nighttime oxidation rates due to reaction with $\mathrm{NO}_{3}$; and (3) organic aerosol was enhanced within the NBL, and in cases without biomass burning influence, this organic aerosol was present at levels in excess of those attributable to primary emissions. The combination of these observations implies a secondary organic aerosol source from reaction of $\mathrm{NO}_{3}$ with BVOCs in the range $0.05-1 \mu \mathrm{g} \mathrm{m}^{-3} \mathrm{~h}^{-1}$. A large organic aerosol source is consistent with regional and global

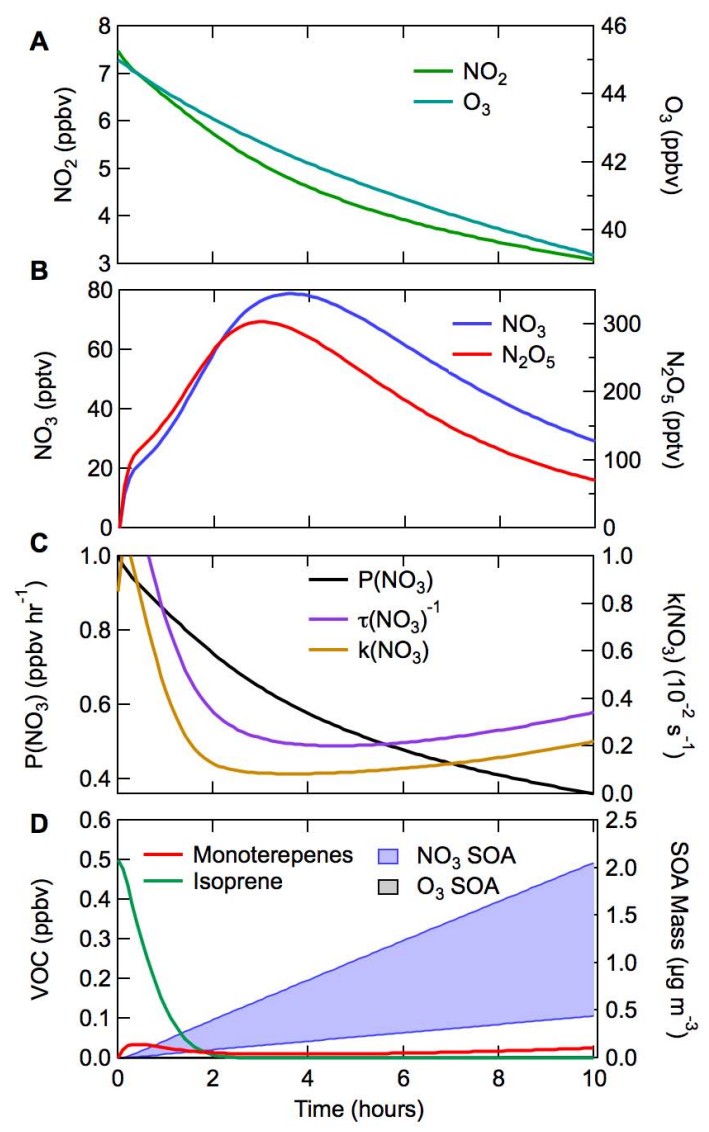

Fig. 18. Same as Fig. 17, except for smaller nitrate radical and BVOC emission rates intended to represent biogenic VOC oxidation over the urban area (see text).

models of $\mathrm{NO}_{3}$-monoterpene oxidation and provides a mechanism by which anthropogenic $\mathrm{NO}_{\mathrm{x}}$ emissions increase the efficiency of organic aerosol production from biogenic emissions. The specific observations and conclusions outlined here will require further comparison to regional models that include NBL schemes and nighttime BVOC oxidation.

Acknowledgements. The preparation of this report is based on work supported by the state of Texas through the Air Quality Research Program administered by the University of Texas at Austin by means of a grant from the Texas Commission on Environmental Quality. The work was also supported in part by NOAA's Atmospheric Chemistry and Climate Program.

Edited by: P. O. Wennberg 


\section{References}

Aiken, A. C., DeCarlo, P. F., and Jiménez, J. L.: Elemental Analysis of Organic Species with Electron Ionization HighResolution Mass Spectrometry, Anal. Chem., 79, 8350-8358, doi:10.1021/ac071150w, 2007.

Aiken, A. C., Salcedo, D., Cubison, M. J., Huffman, J. A., DeCarlo, P. F., Ulbrich, I. M., Docherty, K. S., Sueper, D., Kimmel, J. R., Worsnop, D. R., Trimborn, A., Northway, M., Stone, E. A., Schauer, J. J., Volkamer, R. M., Fortner, E., de Foy, B., Wang, J., Laskin, A., Shutthanandan, V., Zheng, J., Zhang, R., Gaffney, J., Marley, N. A., Paredes-Miranda, G., Arnott, W. P., Molina, L. T., Sosa, G., and Jimenez, J. L.: Mexico City aerosol analysis during MILAGRO using high resolution aerosol mass spectrometry at the urban supersite (T0) - Part 1: Fine particle composition and organic source apportionment, Atmos. Chem. Phys., 9, 6633-6653, doi:10.5194/acp-9-6633-2009, 2009.

Atkinson, R. and Arey, J.: Atmospheric Degradation of Volatile Organic Compounds, Chem. Rev., 103, 4605-4638, 2003.

Atkinson, R., Baulch, D. L., Cox, R. A., Crowley, J. N., Hampson, R. F., Hynes, R. G., Jenkin, M. E., Rossi, M. J., and Troe, J.: Evaluated kinetic and photochemical data for atmospheric chemistry: Volume I - gas phase reactions of $\mathrm{O}_{\mathrm{x}}, \mathrm{HO}_{\mathrm{x}}, \mathrm{NO}_{\mathrm{x}}$ and $\mathrm{SO}_{\mathrm{x}}$ species, Atmos. Chem. Phys., 4, 1461-1738, doi:10.5194/acp-41461-2004, 2004.

Bahreini, R., Dunlea, E. J., Matthew, B. M., Simons, C., Docherty, K. S., DeCarlo, P. F., Jimenez, J. L., Brock, C. A., and Middlebrook, A. M.: Design and operation of a pressure-controlled inlet for airborne sampling with an aerodynamic aerosol lens, Aerosol Sci. and Tech., 42, 465-471, doi:10.1080/02786820802178514, 2008.

Bahreini, R., Ervens, B., Middlebrook, A. M., Warneke, C., de Gouw, J. A., DeCarlo, P. F., Jimenez, J. L., Brock, C. A., Neuman, J. A., Ryerson, T. B., Stark, H., Atlas, E., Brioude, J., Fried, A., Holloway, J. S., Peischl, J., Richter, D., Walega, J., Weibring, P., Wollny, A. G., and Fehsenfeld, F. C.: Organic aerosol formation in urban and industrial plumes near Houston and Dallas, Texas, J. Geophys. Res., 114, D00F16, doi:10.1029/2008JD011493, 2009.

Bahreini, R., Middlebrook, A. M., Brock, C. A., de Gouw, J. A., McKeen, S. A., Williams, L. R., Daumit, K. E., Lambe, A. T., Massoli, P., Canagaratna, M. R., Ahmadov, R., Carrasquillo, A. J., Cross, E. S., Ervens, B., Holloway, J. S., Hunter, J. F., Onasch, T. B., Pollack, I. B., Roberts, J. M., Ryerson, T. B., Warneke, C., Davidovits, P., Worsnop, D. R., and Kroll, J. H.: Mass spectral analysis of organic aerosol formed downwind of the Deepwater Horizon oil spill: Field studies and laboratory confirmations, Environ. Sci. Technol., 46, 8025-8034, 2012.

Brock, C. A., Trainer, M., Ryerson, T. B., Neuman, J. A., Parrish, D. D., Holloway, J. S., Nicks, D. K., Jr., Frost, G. J., Hubler, G., Fehsenfeld, F. C., Wilson, J. C., Reeves, J. M., Lafleur, B. G., Hilbert, H., Atlas, E. L., Donnelly, S. G., Schauffler, S. M., Stroud, V. R., and Wiedinmyer, C.: Particle growth in urban and industrial plumes in Texas, J. Geophys. Res., 108, 4111, doi:10.1029/2002JD002746, 2003.

Brown, S. S. and Stutz, J.: Nighttime Radical Observations and Chemistry, Chem. Soc. Reviews, 41, 6405-6447, doi:10.1039/c2cs35181a, 2012.

Brown, S. S., Stark, H., and Ravishankara, A. R.: Applicability of the Steady-State Approximation to the Interpretation of Atmo- spheric Observations of $\mathrm{NO}_{3}$ and $\mathrm{N}_{2} \mathrm{O}_{5}$, J. Geophys. Res., 108, D174539, doi:10.1029/2003JD003407, 2003.

Brown, S. S., Neuman, J. A., Ryerson, T. B., Trainer, M., Dubé, W. P., Holloway, J. S., Warneke, C., de Gouw, J. A., Donnelly, S. G., Atlas, E., Matthew, B., Middlebrook, A. M., Peltier, R., Weber, R. J., Stohl, A., Meagher, J. F., Fehsenfeld, F. C., and Ravishankara, A. R.: Nocturnal odd-oxygen budget and its implications for ozone loss in the lower troposphere, Geophys. Res. Lett., 33, L08801, doi:10.1029/2006GL025900, 2006.

Brown, S. S., Dubé, W. P., Osthoff, H. D., Stutz, J., Ryerson, T. B., Wollny, A. G., Brock, C. A., Warneke, C., de Gouw, J. A., Atlas, E., Neuman, J. A., Holloway, J. S., Lerner, B. M., Williams, E. J., Kuster, W. C., Goldan, P. D., Angevine, W. M., Trainer, M., Fehsenfeld, F. C., and Ravishankara, A. R.: Vertical profiles in $\mathrm{NO}_{3}$ and $\mathrm{N}_{2} \mathrm{O}_{5}$ measured from an aircraft: Results from the NOAA P-3 and surface platforms during NEAQS 2004, J. Geophys. Res., 112, D22304, doi:10.1029/2007JD008883, 2007a.

Brown, S. S., Dubé, W. P., Osthoff, H. D., Wolfe, D. E., Angevine, W. M., and Ravishankara, A. R.: High resolution vertical distributions of $\mathrm{NO}_{3}$ and $\mathrm{N}_{2} \mathrm{O}_{5}$ through the nocturnal boundary layer, Atmos. Chem. Phys., 7, 139-149, doi:10.5194/acp-7-139-2007, 2007b.

Brown, S. S., deGouw, J. A., Warneke, C., Ryerson, T. B., Dubé, W. P., Atlas, E., Weber, R. J., Peltier, R. E., Neuman, J. A., Roberts, J. M., Swanson, A., Flocke, F., McKeen, S. A., Brioude, J., Sommariva, R., Trainer, M., Fehsenfeld, F. C., and Ravishankara, A. R.: Nocturnal isoprene oxidation over the Northeast United States in summer and its impact on reactive nitrogen partitioning and secondary organic aerosol, Atmos. Chem. Phys., 9, 30273042, doi:10.5194/acp-9-3027-2009, 2009a.

Brown, S. S., Dubé, W. P., Fuchs, H., Ryerson, T. B., Wollny, A. G., Brock, C. A., Bahreini, R., Middlebrook, A. M., Neuman, J. A., Atlas, E., Trainer, M., Fehsenfeld, F. C., and Ravishankara, A. R.: Reactive uptake coefficients for $\mathrm{N}_{2} \mathrm{O}_{5}$ determined from aircraft measurements during TexAQS 2006; Comparison to current model parameterizations, J. Geophys. Res., 114, D00F10, doi:10.1029/2008JD011679, 2009b.

Brown, S. S., Dubé, W. P., Peischl, J., Ryerson, T. B., Atlas, E., Warneke, C., de Gouw, J., Te Lintel Hekkert, S., Brock, C. A., Flocke, F., Trainer, M., Parrish, D. D., Fehsenfeld, F. C., and Ravishankara, A. R.: Budgets for nocturnal VOC oxidation by nitrate radicals aloft during the 2006 Texas Air Quality Study, J. Geophys. Res., 116, D24305, doi:10.1029/2011JD016544, 2011.

Brown, S. S., Dubé, W. P., Karamchandari, P., Yarwood, G., Peischl, J., Ryerson, T. B., Neuman, J. A., Nowak, J. B., Holloway, J. S., Washenfelder, R. A., Brock, C. A., Frost, G. J., Trainer, M., Parrish, D. D., Fehsenfeld, F. C., and Ravishankara, A. R.: The effects of $\mathrm{NO}_{\mathrm{x}}$ control and plume mixing on nighttime chemical processing of plumes from coal-fired power plants, J. Geophys. Res., 117, D07304, doi:10.1029/2011JD016954, 2012.

Chang, W. L., Bhave, P. V., Brown, S. S., Riemer, N., Stutz, J., and Dabdub, D.: Heterogeneous Atmospheric Chemistry, Ambient Measurements, and Model Calculations of $\mathrm{N}_{2} \mathrm{O}_{5}$ : A Review, Aerosol Sci. Technol., 45, 655-685, 2011.

Day, D. A., Liu, S., Russell, L. M., and Ziemann, P. J.: Organonitrate group concentrations in submicron particles with high nitrate and organic fractions in coastal southern California, Atmos. Environ., 44, 1970-1979, 2010. 
de Gouw, J. A. and Jimenez, J. L.: Organic Aerosols in the Earth's Atmosphere, Environ. Sci. Technol., 43, 7614-7618, 2009.

de Gouw, J. A. and Warneke, C.: Measurements of volatile organic compounds in the Earth's atmosphere using proton-transferreaction mass spectrometry, Mass. Spec. Rev., 26, 223-257, 2007.

de Gouw, J. A., Goldan, P. D., Warneke, C., Kuster, W. C., Roberts, J. M., Marchewka, M., Bertman, S. B., Pszenny, A. A. P., and Keene, W. C.: Validation of proton transfer reaction-mass spectrometry (PTR-MS) measurements of gas-phase organic compounds in the atmosphere during the New England Air Quality Study (NEAQS) in 2002, J. Geophys. Res., 108, D214682, doi:10.1029/2003JD003863, 2003.

de Gouw, J. A., Middlebrook, A. M., Warneke, C., Goldan, P. D., Kuster, W. C., Roberts, J. M., Fehsenfeld, F. C., Worsnop, D. R., Canagaratna, M. R., Pszenny, A. A. P., Keene, W. C., Marchewka, M., Bertman, S. B., and Bates, T. S.: Budget of organic carbon in a polluted atmosphere: Results from the New England Air Quality Study in 2002, J. Geophys. Res.-Atmos., 110, D16305, doi:10.1029/2004JD005623, 2005.

de Gouw, J. A., Brock, C. A., Atlas, E., Bates, T. S., Fehsenfeld, F. C., Goldan, P. D., Holloway, J. S., Kuster, W. C., Lerner, B. M., Matthew, B. M., Middlebrook, A. M., Onasch, T. B., Peltier, R. E., Quinn, P. K., Senff, C. J., Stohl, A., Sullivan, A. P., Trainer, M., Warneke, C., Weber, R. J., and Williams, E. J.: Sources of particulate matter in the northeastern United States in summer: 1. Direct emission and secondary formation of organic matter in urban plumes, J. Geophys. Res., 113, D08301, doi:10.1029/2007JD009243, 2008.

Dubé, W. P., Brown, S. S., Osthoff, H. D., Nunley, M. R., Ciciora, S. J., Paris, M. W., McLaughlin, R. J., and Ravishankara, A. R.: Aircraft instrument for simultaneous, in-situ measurements of $\mathrm{NO}_{3}$ and $\mathrm{N}_{2} \mathrm{O}_{5}$ via cavity ring-down spectroscopy, Rev. Sci. Instr., 77, 034101, doi:10.1063/1.2176058, 2006.

Farmer, D. K., Matsunaga, A., Docherty, K. S., Surratt, J. D., Seinfeld, J. H., Ziemann, P. J., and Jimenez, J. L.: Response of the Aerosol Mass Spectrometer to organonitrates and organosulfates and implications for field studies, P. Natl. Acad. Sci., 107, 66706675, doi:10.1073/pnas.0912340107, 2010.

Fry, J. L., Kiendler-Scharr, A., Rollins, A. W., Wooldridge, P. J., Brown, S. S., Fuchs, H., Dubé, W., Mensah, A., dal Maso, M., Tillmann, R., Dorn, H.-P., Brauers, T., and Cohen, R. C.: Organic nitrate and secondary organic aerosol yield from $\mathrm{NO}_{3}$ oxidation of $\beta$-pinene evaluated using a gas-phase kinetics/aerosol partitioning model, Atmos. Chem. Phys., 9, 14311449, doi:10.5194/acp-9-1431-2009, 2009.

Fry, J. L., Kiendler-Scharr, A., Rollins, A. W., Brauers, T., Brown, S. S., Dorn, H.-P., Dubé, W. P., Fuchs, H., Mensah, A., Rohrer, F., Tillmann, R., Wahner, A., Wooldridge, P. J., and Cohen, R. C.: SOA from limonene: role of $\mathrm{NO}_{3}$ in its generation and degradation, Atmos. Chem. Phys., 11, 3879-3894, doi:10.5194/acp-113879-2011, 2011.

Fuchs, H., Dubé, W. P., Ciciora, S. J., and Brown, S. S.: Determination of Inlet Transmission and Conversion Efficiencies for in Situ Measurements of the Nocturnal Nitrogen Oxides, $\mathrm{NO}_{3}$, $\mathrm{N}_{2} \mathrm{O}_{5}$ and $\mathrm{NO}_{2}$, via Pulsed Cavity Ring-Down Spectroscopy, Anal. Chem., 80, 6010-6017, doi:10.1021/ac8007253, 2008.

Fuentes, J. D., Lerdau, M., Atkinson, R., Baldocchi, D., Bottenheim, J. W., Ciccioli, P., Lamb, B., Geron, C., Gu, L., Guenther,
A., Sharkey, T. D., and Stockwell, W.: Biogenic Hydrocarbons in the Atmospheric Boundary Layer: A Review, B. Am. Meteorol. Soc., 81, 1537-1575, 2000.

Geyer, A. and Platt, U.: Temperature dependence of the $\mathrm{NO}_{3}$ loss frequency: A new indicator for the contribution of $\mathrm{NO}_{3}$ to the oxidation of monoterpenes and NOx removal in the atmosphere, J. Geophys. Res., 107, D214431, doi:10.1029/2001JD001215, 2002.

Gong, H., Matsunaga, A., and Ziemann, P. J.: Products and Mechanism of Secondary Organic Aerosol Formation from Reactions of Linear Alkenes with NO3 Radicals, J. Phys. Chem., 109, 43124324, 2005.

Griffin, R. J., Cocker, D. R., III, Flagan, R. C., and Seinfeld, J. H.: Organic aerosol formation from the oxidation of biogenic hydrocarbons, J. Geophys. Res., 104, 3555-3567, 1999.

Hallquist, M., Wängberg, I., Ljungstrom, E., Barnes, I., and Becker, K. H.: Aerosol and Product Yields from $\mathrm{NO}_{3}$ Radical-Initiated Oxidation of Selected Monoterpenes, Environ. Sci. Technol., 33, 553-559, 1999.

Hodzic, A., Jimenez, J. L., Madronich, S., Canagaratna, M. R., DeCarlo, P. F., Kleinman, L., and Fast, J.: Modeling organic aerosols in a megacity: potential contribution of semi-volatile and intermediate volatility primary organic compounds to secondary organic aerosol formation, Atmos. Chem. Phys., 10, 5491-5514, doi:10.5194/acp-10-5491-2010, 2010.

Hoyle, C. R., Berntsen, T., Myhre, G., and Isaksen, I. S. A.: Secondary organic aerosol in the global aerosol - chemical transport model Oslo CTM2, Atmos. Chem. Phys., 7, 5675-5694, doi:10.5194/acp-7-5675-2007, 2007.

Hoyle, C. R., Myhre, G., Berntsen, T. K., and Isaksen, I. S. A.: Anthropogenic influence on SOA and the resulting radiative forcing, Atmos. Chem. Phys., 9, 2715-2728, doi:10.5194/acp-9-27152009, 2009.

Iinuma, Y., Müller, C., Berndt, T., Böge, O., Claeys, M., and Herrmann, H.: Evidence for the Existence of Organosulfates from b-Pinene Ozonolysis in Ambient Secondary Organic Aerosol, Environ. Sci. Technol., 41, 6678-6683, doi:10.1021/es070938t, 2007.

Jenkin, M. E. and Boyd, A. A.: Peroxy radical kinetics resulting from the $\mathrm{OH}$ initiatied oxidation of 1,3-butadiene, 2,3-dimethyl1,3-butadiene and isoprene, J. Atmos. Chem., 39, 267-298, 1998.

Jimenez, J. L., Canagaratna, M. R., Donahue, N. M., Prevot, A. S. H., Zhang, Q., Kroll, J. H., DeCarlo, P. F., Allan, J. D., Coe, H., Ng, N. L., Aiken, A. C., Docherty, K. S., Ulbrich, I. M., Grieshop, A. P., Robinson, A. L., Duplissy, J., Smith, J. D., Wilson, K. R., Lanz, V. A., Hueglin, C., Sun, Y. L., Tian, J., Laaksonen, A., Raatikainen, T., Rautiainen, J., Vaattovaara, P., Ehn, M., Kulmala, M., Tomlinson, J. M., Collins, D. R., Cubison, M. J., Dunlea, E. J., Huffman, J. A., Onasch, T. B., Alfarra, M. R., Williams, P. I., Bower, K., Kondo, Y., Schneider, J., Drewnick, F., Borrmann, S., Weimer, S., Demerjian, K., Salcedo, D., Cottrell, L., Griffin, R., Takami, A., Miyoshi, T., Hatakeyama, S., Shimono, A., Sun, J. Y., Zhang, Y. M., Dzepina, K., Kimmel, J. R., Sueper, D., Jayne, J. T., Herndon, S. C., Trimborn, A. M., Williams, L. R., Wood, E. C., Middlebrook, A. M., Kolb, C. E., Baltensperger, U., and Worsnop, D. R.: Evolution of Organic Aerosols in the Atmosphere, Science, 326, 1525-1529, 2009.

Kroll, J. H., Smith, J. D., Worsnop, D. R., and Wilson, K. R.: Characterization of lightly oxidized organic aerosol fomred from teh 
photochemical aging of diesel exhaust particles, Environ. Chem., 9, 211-220, 2012.

Lemire, K. R., Allen, D. T., Klouda, G. A., and Lewis, C. W.: Fine particulate matter source attribution for Southeast Texas using ${ }^{14} \mathrm{C} /{ }^{13} \mathrm{C}$ Ratios, J. Geophys. Res., 107, 4613, doi:10.1029/2002JD002339, 2002.

Lewis, C. W., Klouda, G. A., and Ellenson, W.: Radiocarbon measurement of the biogenic contribution to summertime PM-2.5 ambient aerosol in Nashville, TN, Atmos. Environ., 38, 60536061, 2004.

Marcolli, C., Canagaratna, M. R., Worsnop, D. R., Bahreini, R., de Gouw, J. A., Warneke, C., Goldan, P. D., Kuster, W. C., Williams, E. J., Lerner, B. M., Roberts, J. M., Meagher, J. F., Fehsenfeld, F. C., Marchewka, M., Bertman, S. B., and Middlebrook, A. M.: Cluster Analysis of the Organic Peaks in Bulk Mass Spectra Obtained During the 2002 New England Air Quality Study with an Aerodyne Aerosol Mass Spectrometer, Atmos. Chem. Phys., 6, 5649-5666, doi:10.5194/acp-6-5649-2006, 2006.

McLaren, R., Salmon, R. A., Liggio, J., Hayden, K. L., Analuf, K., and Leaitch, W. R.: Nighttime chemistry at a rural site in the Lower Fraser Valley, Atmos. Environ., 38, 5837-5848, 2004.

Middlebrook, A. M., Bahreini, R., Jimenez, J. L., and Canagaratna, M. R.: Evaluation of Composition-Dependent Collection Efficiencies for the Aerodyne Aerosol Mass Spectrometer using Field Data, Aerosol Sci. Technol., 46, 258-271, doi:10.1080/02786826.2011.620041, 2012.

Mohr, C., DeCarlo, P. F., Heringa, M. F., Chirico, R., Slowik, J. G., Richter, R., Reche, C., Alastuey, A., Querol, X., Seco, R., Peñuelas, J., Jiménez, J. L., Crippa, M., Zimmermann, R., Baltensperger, U., and Prévôt, A. S. H.: Identification and quantification of organic aerosol from cooking and other sources in Barcelona using aerosol mass spectrometer data, Atmos. Chem. Phys., 12, 1649-1665, doi:10.5194/acp-12-1649-2012, 2012.

Ng, N. L., Kwan, A. J., Surratt, J. D., Chan, A. W. H., Chhabra, P. S., Sorooshian, A., Pye, H. O. T., Crounse, J. D., Wennberg, P. O., Flagan, R. C., and Seinfeld, J. H.: Secondary organic aerosol (SOA) formation from reaction of isoprene with nitrate radicals $\left(\mathrm{NO}_{3}\right)$, Atmos. Chem. Phys., 8, 4117-4140, doi:10.5194/acp-84117-2008, 2008.

Parrish, D. D., Allen, D. T., Bates, T. S., Estes, M., Fehsenfeld, F. C., Feingold, G., Ferrare, R., Hardesty, R. M., Meagher, J. F., Nielsen-Gammon, J., Pierce, R. B., Ryerson, T. B., Seinfeld, J. H., and Williams, E. J.: Overview of the Second Texas Air Quality Study (TexAQS II) and the Gulf of Mexico Atmospheric Composition and Climate Study (GoMACCS), J. Geophys. Res., 114, D00F13, doi:10.1029/2009JD011842, 2008.

Platt, U. F., Winer, A. M., Bierman, H. W., Atkinson, R., and Pitts, J. N., Jr.: Measurement of Nitrate Radical Concentrations in Continental Air, Environ. Sci. Technol., 18, 365-369, 1984.

Pye, H. O. T., Chan, A. W. H., Barkley, M. P., and Seinfeld, J. H.: Global modeling of organic aerosol: the importance of reactive nitrogen $\left(\mathrm{NO}_{\mathrm{x}}\right.$ and $\left.\mathrm{NO}_{3}\right)$, Atmos. Chem. Phys., 10, 1126111276, doi:10.5194/acp-10-11261-2010, 2010.

Rollins, A. W., Kiendler-Scharr, A., Fry, J. L., Brauers, T., Brown, S. S., Dorn, H.-P., Dubé, W. P., Fuchs, H., Mensah, A., Mentel, T. F., Rohrer, F., Tillmann, R., Wegener, R., Wooldridge, P. J., and Cohen, R. C.: Isoprene oxidation by nitrate radical: alkyl nitrate and secondary organic aerosol yields, Atmos. Chem. Phys., 9, 6685-6703, doi:10.5194/acp-9-6685-2009, 2009.
Rollins, A. W., Browne, E. C., Min, K. E., Pusede, S. E., Wooldridge, P. J., Gentner, D. R., Goldstein, A. H., Liu, S., Day, D. A., Russell, L. M., and Cohen, R. C.: Evidence for $\mathrm{NO}_{\mathrm{x}}$ Control over Nighttime SOA Formation, Science, 337, 1210-1212, 2012.

Russell, M. and Allen, D. T.: Predicting secondary organic aerosol formation rates in southeast Texas, J. Geophys. Res., 110, D07S17, doi:10.1029/2004JD004722, 2005.

Ryerson, T. B., Buhr, M. P., Frost, G. J., Goldan, P. D., Holloway, J. S., Hübler, G., Jobson, B. T., Kuster, W. C., McKeen, S. A., Parrish, D. D., Roberts, J. M., Sueper, D. T., Trainer, M., Williams, J., and Fehsenfeld, F. C.: Emission lifetimes and ozone formation in power plant plumes, J. Geophys. Res., 103, 22569-22583, 1998.

Ryerson, T. B., Huey, L. G., Knapp, K., Neuman, J. A., Parrish, D. D., Sueper, D. T., and Fehsenfeld, F. C.: Design and initial characterization of an inlet for gas-phase $\mathrm{NO}_{\mathrm{y}}$ measurements from aircraft, J. Geophys. Res., 104, 5483-5492, 1999.

Ryerson, T. B., Williams, E. J., and Fehsenfeld, F. C.: An efficient photolysis system for fast response $\mathrm{NO}_{2}$ measurements, J. Geophys. Res., 105, 26447-26461, 2000.

Schauffler, S. M., Atlas, E., Blake, D. R., Flocke, F., Lueb, R. A., Lee-Taylor, J. M., Stroud, V., and Travnicek, W.: Distributions of brominated organic compounds in the troposphere and lower stratosphere, J. Geophys. Res., 104, 21513-21536, 1999.

Schichtel, B., Malm, W. C., Bench, G., Fallon, S., McDade, C. E., Chow, J. C., and Watson, J. G.: Fossil and contemporary fine particulate carbon fractions at 12 rural and urban sites in the United States, J. Geophys. Res., 113, D02311, doi:10.1029/2007JD008605, 2008.

Schwarz, J. P., Gao, R. S., Spackman, J. R., Watts, L. A., Thomson, D. S., Fahey, D. W., Ryerson, T. B., Peischl, J., Holloway, J. S., Trainer, M., Frost, G. J., Baynard, T., de Gouw, J. A., and Del Negro, L.: Measurement of the mixing state, mass, and optical size of individual black carbon particles in urban and biomass burning emissions, Geophys. Res. Lett., 35, L13810, doi:10.1029/2008GL033968, 2008.

Spracklen, D. V., Jimenez, J. L., Carslaw, K. S., Worsnop, D. R., Evans, M. J., Mann, G. W., Zhang, Q., Canagaratna, M. R., Allan, J., Coe, H., McFiggans, G., Rap, A., and Forster, P.: Aerosol mass spectrometer constraint on the global secondary organic aerosol budget, Atmos. Chem. Phys., 11, 12109-12136, doi:10.5194/acp-11-12109-2011, 2011.

Vaughan, S., Canosa-Mas, C. E., Pfrang, C., Shallcross, D. E., Watson, L. R., and Wayne, R. P.: Kinetic studies of reactions of nitrate radical $\left(\mathrm{NO}_{3}\right)$ with peroxy radicals $\left(\mathrm{RO}_{2}\right)$ : an indirect source of $\mathrm{OH}$ at night?, Phys. Chem. Chem. Phys., 8, 3749-3760, 2006.

Volkamer, R., Jimenez, J. L., San Martini, F., Dzepina, K., Zhang, Q., Salcedo, D., Molina, L. T., Worsnop, D. R., and Molina, M. J.: Secondary organic aerosol formation from anthropogenic air pollution: Rapid and higher than expected, Geophys. Res. Lett., 33, L17811, doi:10.1029/2006GL026899, 2006.

Warneke, C., de Gouw, J. A., Del Negro, L., Brioude, J., McKeen, S., Stark, H., Kuster, W. C., Goldan, P. D., Trainer, M., Fehsenfeld, F. C., Wiedinmyer, C., Guenther, A. B., Hansel, A., Wisthaler, A., Atlas, E., Holloway, J. S., Ryerson, T. B., Peischl, J., Huey, L. G., and Hanks, A. T. C.: Biogenic emission measurement and inventories determination of biogenic emis- 
sions in the eastern United States and Texas and comparison with biogenic emission inventories, J. Geophys. Res., 115, D00F18, doi:10.1029/2009JD012445, 2010.

Weber, R. J., Sullivan, A. P., Peltier, R., Russell, A., Yan, B., Zheng, M., de Gouw, J. A., Warneke, C., Brock, C. A., Holloway, J. S., Atlas, E. L., and Edgerton, E.: A study of secondary organic aerosol formation in the anthropogenicinfluenced southeastern United States, J. Geophys. Res., 112, D13302, doi:10.1029/2007JD008408, 2007.

Winer, A. M., Atkinson, R., and Pitts, J. N. J.: Gaseous Nitrate Radical: Possible Nighttime Atmospheric Sink for Biogenic Organic Compounds, Science, 224, 156-158, 1984.

Young, C. J., Washenfelder, R. A., Mielke, L. H., Osthoff, H. D., Veres, P., Cochran, A. K., VandenBoer, T. C., Stark, H., Flynn, J., Grossberg, N., Haman, C. L., Lefer, B., Gilman, J. B., Kuster, W. C., Tsai, C., Pikelnaya, O., Stutz, J., Roberts, J. M., and Brown, S. S.: Vertically resolved measurements of nighttime radical reservoirs in Los Angeles and their contribution to the urban radical budget, Environ. Sci. Technol., 46, 10965-10973, doi:10.1021/es302206a, 2012.
Zhang, Q., Alfarra, M. R., Worsnop, D. R., Allan, J. D., Coe, H., Canagaratna, M. R., and Jimenez, J. L.: Deconvolution and quantification of hydrocarbon-like and oxygenated organic aerosols based on Aerosol Mass Spectromentry, Environ. Sci. Technol., 39, 4938-4952, 2005a.

Zhang, Q., Worsnop, D. R., Canagaratna, M. R., and Jimenez, J. L.: Hydrocarbon-like and oxygenated organic aerosols in Pittsburgh: insights into sources and processes of organic aerosols, Atmos. Chem. Phys., 5, 3289-3311, doi:10.5194/acp-5-32892005, 2005b.

Zhang, Q., Jimenez, J. L., Canagaratna, M. R., Allan, J. D., Coe, H., Ulbrich, I., Alfarra, M. R., Takami, A., Middlebrook, A. M., Sun, Y. L., Dzepina, K., Dunlea, E., Docherty, K. S., DeCarlo, P. F., Salcedo, D., Onasch, T. B., Jayne, J. T., Miyoshi, T., Shimono, A., Hatakeyama, S., Takegawa, N., Kondo, Y., Scheider, J., Drewnick, F., Borrman, S., Weimer, S., Demerjian, K. L., Williams, P. I., Bower, K., Bahreini, R., Cottrell, L., Griffin, R. J., Rautiainen, J., Sun, J. Y., Zhang, Y. M., and Worsnop, D. R.: Ubiquity and dominance of oxygenated species in organic aerosols in anthropogenically-influenced Northern Hemisphere midlatitudes, Geophys. Res. Lett., 34, L13801, doi:10.1029/2007GL029979, 2007. 